The Historical fournal, 46, 4 (2003), pp. 779-8I5 C 2003 Cambridge University Press DOI: 10.1017/Soor8246Xo3003303 Printed in the United Kingdom

\title{
MIRACLES AND THE COUNTER-REFORMATION MISSION TO ENGLAND*
}

\author{
ALEXANDRA WALSHAM \\ University of Exeter
}

\begin{abstract}
This article explores the way in which the Counter Reformation priests sent to England after 1574 cultivated and harnessed the culture of the miraculous in their efforts to reform and evangelize the populace and to defend doctrines and practices assaulted by Protestant polemicists. Drawing on the insights emerging from recent research on Catholic renewal on the Continent, it shows how the seminary clergy and especially the Fesuits fostered traditional beliefs and practices associated with saints, relics, and sacramentals and exploited the potential of exorcisms and visions for didactic and proselytizing purposes. Close examination of these strategies serves to question some existing assumptions about the nature, objectives, and impact of the English Catholic mission and to illuminate the particular challenges that persecution presented to a movement determined to purge popular piety of its 'superstitious' accretions. It underlines the tensions between ecclesiastical direction and lay initiative which characterized a context in which Catholicism was a minority Church and highlights the frictions and divisions which these attempts to utilize supernatural power stimulated within the ranks of the Counter Reformation priesthood itself.
\end{abstract}

I

Over the last decade, historical analysis of the character and consequences of the Catholic or Counter Reformation has experienced a significant change of direction and emphasis. A generation ago, under the influence of Jean Delumeau, Robert Muchembled and John Bossy, it was commonplace to present the movement as part of a wider trend which resulted in the 'triumph of Lent', a parallel manifestation of Protestantism's drive to eradicate vulgar 'superstition', correct immoral conduct, and instil a more interiorized, spiritual, and theologically sound piety in the populace. According to these accounts, in its campaign for 'Christianization' reformed Catholicism actively distanced itself from the excesses and abuses of late medieval religious culture and made strenuous but often fiercely

* I am grateful to Patrick Collinson, Anne Dillon, Simon Ditchfield, Mark Greengrass, Sarah Hamilton, Trevor Johnson, Peter Marshall, Ethan Shagan, Andrew Spicer, and the readers for this journal for constructive criticisms of earlier drafts of this article. It has also benefited from the comments of those who heard versions of it read as seminar papers in Denver, Birmingham, and Oxford. 
resisted efforts to purge it of its 'pagan' and 'magical' features. ${ }^{1}$ This tendency to stress the coercive, disciplinary, and acculturating aspects of Catholic reform has been powerfully reinforced by the work of Heinz Schilling and other advocates of the so-called 'confessionalization' thesis. ${ }^{2}$

Recent research, however, has begun to revise and modify our understanding of the relationship between traditional and Tridentine religion. Studies by David Gentilcore, Trevor Johnson, Philip Soergel, Marc Forster, Louis Chatellier, and others have underlined the continuities between medieval and Counter Reformation piety and highlighted the manner in which the Catholic reformers revived and mobilized rather than simply suppressed older devotional practices. Both in the rural fringe and frontier districts of loyal Catholic countries and in formerly Protestant regions which experienced state-sponsored programmes of re-Catholicization, the clergy fuelled the desire of the laity for contact with the sacred. In these processes, the members of new and rejuvenated religious orders played a prominent role, supplementing the pastoral endeavours of the parochial priesthood and compensating for its slow emergence as a professional force capable of instructing the faithful and implanting in them true Christian values. Seeking to exploit what they perceived to be one of Protestantism's most glaring weaknesses, officials and reformers in Bavaria, the Upper Rhine Palatinate, and other areas of the Holy Roman Empire advertised Catholicism's superior thaumaturgic capacities and zealously propagated the idea of a sacralized landscape. $^{3}$ Employing strategies of accommodation similar to those used in Asia and the New World, in southern Italy Jesuit, Lazarist, and Redemptorist missionaries fostered lay fascination with the miraculous in a determination to 'adapt themselves to the people's capabilities' and 'meet popular culture

${ }^{1}$ Jean Delumeau, Catholicism between Luther and Voltaire (London, 1977); Robert Muchembled, Popular culture and elite culture in France, I400-I750 (Baton Rouge, I985) (French edition I978); John Bossy, 'The Counter Reformation and the people of Catholic Europe', Past and Present, 47 (I97o), pp. $5^{\mathrm{I}-70}$; idem, Christianity in the west, I400-I700 (Oxford, 1985).

${ }^{2}$ Heinz Schilling, 'Confessional Europe', in Thomas A. Brady et al., eds., Handbook of European history, I400-I80o (2 vols., Leiden, I995), pp. 64I-8I ; Wolfgang Reinhard, 'Pressures towards confessionalization? Prolegomena to a theory of the confessional age', in C. Scott Dixon, ed., The German Reformation (Oxford, 1999), pp. I69-92; R. Po-Chia Hsia, Social discipline in the Reformation: central Europe, I550-I750 (London, I989).

${ }^{3}$ The trends evident in the English-language scholarship reflect similar developments in French, German, Italian, and Spanish research. See Trevor Johnson, 'The recatholicisation of the Upper Palatinate (c. I62I-c. I700)' (PhD dissertation, Cambridge, I99I); idem, 'Blood, tears and Xavierwater: Jesuit missionaries and popular religion in the eighteenth-century Upper Palatinate', in Bob Scribner and Trevor Johnson, eds., Popular religion in Germany and central Europe, I400-I80o (Basingstoke, 1996), pp. I83-202; Philip M. Soergel, Wondrous in his saints: Counter-Reformation propaganda in Bavaria (Berkeley, 1993); Marc R. Forster, Catholic revival in the age of the Baroque: religious identity in southwest Germany, ${ }^{155^{-1}} 75^{\circ}$ (Cambridge, 200I). See also Jason K. Nye, 'Not like us: Catholic identity as a defence against Protestantism in Rottweil, $1560-1618$ ', and Maria Craciun, 'Traditional practices: Catholic missionaries and Protestant religious practice in Transylvania', in Helen Parish and William G. Naphy, eds., Religion and superstition in Reformation Europe (Manchester, 2002), pp. 47-74, 75-93 respectively. 
halfway'. ${ }^{4}$ In provincial France and Spain, similarly subtle techniques of substitution and interchange resulted in the 'gentle evolution' of a reformed Catholicism at the core of which remained enduring symbols of sanctity. ${ }^{5}$ The keynotes of current interpretation of the Catholic renewal are thus negotiation and creative compromise rather than antagonism, confrontation, and mutual intolerance. $^{6}$

This shift in scholarly perception has yet to leave its imprint upon the historiography of post-Reformation English Catholicism. Placing the Catholic mission to Elizabethan and early Stuart England firmly against the backdrop of Continental developments, this article investigates the ways in which the seminary priests and Jesuits sent across the Channel after I574 deliberately and skilfully harnessed supernatural power in their attempts to combat heresy, reinforce contested tenets, reclaim backsliders, and win converts to their cause. In their struggle to sustain and spread the illicit Catholic faith, I shall suggest, they too found miracles, visions, and exorcisms very effective as proselytizing tools. Closer examination of these neglected evangelical strategies may not only reanimate debates about the nature, objectives, and impact of the English missionary enterprise but also shed fresh light on how confessional identities were forged in sixteenth- and seventeenth-century Europe as a whole. Simultaneously, it may help to clarify the challenges which the condition of proscription presented to a movement intent upon policing the boundary between orthodox piety and popular 'superstition'.

In England, by contrast with much of the Continent, Catholicism was a minority Church which not only lacked the episcopal infrastructure and political support enjoyed by Tridentine reformers abroad but also suffered from a chronic shortage of clerical personnel. Even after I6oo, when the number of regular and secular clergy in service underwent rapid expansion, the quotient of

4 David Gentilcore, From bishop to witch: the system of the sacred in early modern Terra d'Otranto (Manchester, I992); idem, "Adapt yourselves to the people's capabilities": missionary strategies, methods and impact in the kingdom of Naples, I600-I80o', foumal of Ecclesiastical History, 45 (I994), pp. $269-94$.

5 Louis Chatellier, The religion of the poor: rural missions in Europe and the formation of modern Catholicism, c. I5OO-c. I80o, trans. Brian Pearce (Cambridge, I997; first publ. in French I993), esp. ch. 9, quotation at p. I82. See also Philip T. Hoffman, Church and community in the diocese of Lyon (New Haven, I984), esp. chs. 2-3; Keith P. Luria, Territories of grace: cultural change in the seventeenth-century diocese of Grenoble (Berkeley, I99I); E. C. Tingle, 'The sacred space of Julien Maunoir: the re-Christianising of the landscape in seventeenth-century Britanny', in Will Coster and Andrew Spicer, eds., Sacred space: the redefinition of sanctity in early modern Europe (Cambridge, forthcoming). Henry Kamen remarks that in Catalonia the Church cultivated aspects of traditional piety in a way which 'merely intensified and vulgarised their use': The phoenix and the flame: Catalonia and the Counter Reformation (New Haven, I993), pp. I36-7. See also William A. Christian, Local religion in sixteenth-century Spain (Princeton, I98I); Sarah T. Nalle, God in La Mancha: religious reform and the people of Cuenca, I500-I620 (Baltimore, I992), esp. chs. 4-5.

6 Recent surveys reflect these trends: R. Po-Chia Hsia, The world of Catholic renewal, $1540-1770$ (Cambridge, I998), esp. ch. I3; Michael Mullett, The Catholic Reformation (London and New York, I999), esp. ch. 6; Robert Bireley, The refashioning of Catholicism, I450-I7oo: a reassessment of the Counter Reformation (Basingstoke, I999), esp. ch. 5. It may be commented that the historiography of early modern Protestantism has traced a parallel path of reinterpretation. 
priests per head of population remained very low. As in Ireland and the northern Netherlands, this was a situation which provided considerable scope for lay independence. ${ }^{7}$ It was also a context in which the clergy arguably had an added incentive to make tactical concessions to the indigenous culture by which they were confronted. Such observations pose particular problems for polarized models involving the repression of 'popular' priorities and their replacement by 'elite' values and the superimposition of universal standards upon vernacular practices. Post-Reformation England is an arena in which we have an opportunity to observe a far more complex set of cultural transactions at work.

Ironically, some of the evidence on which this article rests is hostile in origin. Viciously satirical Protestant tracts designed to expose popery as the epitome of evil and falsehood yield a rich harvest of material on the Catholic culture of miracles. In their determination to uphold the axiom that miracles had ceased, polemicists like Samuel Harsnet, John Gee, and Richard Sheldon devoted much space to describing the 'lying wonders', 'mendacious prodigies', and 'egregious impostures' by which the Jesuits and their secular brethren sought to seduce the credulous laity and prop up the reputation of the Antichristian papacy. Even as they contemptuously dismissed these 'Popish tales' and 'Ignatian fables', they preserved them for posterity in print. $^{8}$

The two other main sources for this study are the correspondence which the missionaries sent to their superiors in Rome and the Low Countries and the stories which circulated orally, scribally, and typographically among Elizabethan and early Stuart Catholics in England. Quite apart from the fact of its haphazard survival, this material is scarcely unproblematic. The reports which leading Catholic clergy such as William Weston and Henry Garnet smuggled out to Cardinal Allen, the Jesuit General Claude Aquaviva, and other leading figures tended to be upbeat assessments of the success of their endeavours despite cruel persecution. The Jesuit Annual Letters, which start in the early part of the Jacobean period, are also tainted by a militant, triumphalist tone. Designed to

7 For the size and expansion of the mission, see John Bossy, The English Catholic community, I570-1850 (London, I975), ch. Io. For Ireland and the Netherlands, see Raymond Gillespie, Devoted people: belief and religion in early modern Ireland (Manchester, I997); Willem Frijhoff, 'La function du miracle dans une minorité catholique: les Provinces-Unies au XVIIe siècle', Revue d'histoire de la spiritualité, 48 (I972), pp. I5I-78; Mathieu G. Spiertz, 'Priest and layman in a minority church: the Roman Catholic Church in the northern Netherlands, I592-I686', in W.J. Sheils and Diana Wood, eds., The ministry: clerical and lay, Studies in Church History 26 (Oxford, I989), pp. 287-30I. The situation in France was more ambiguous, but many similarities are apparent: see Mark Greengrass, 'Miracles and the peregrinations of the holy in France during the Wars of Religion', in José Pedro Paiva, ed., Religious ceremonials and images: power and social meaning (I4OO-I75o) (Coimbra, 2002), pp. 389-4I4.

8 See Samuel Harsnet, A declaration of egregious popish impostures (London, I6o4); Robert Tynley, Two learned sermons (London, I6o9), pp. 53-65; William Crashaw, The Fesuites gospel (London, i6ro); John Gee, The foot out of the snare (London, I624); Richard Sheldon, Survey of the miracles of the Church of Rome (London, I6I6). In this article, I deliberately evade the issue of whether or not such miracles were indeed faked and feigned: such allegations complicate rather than invalidate the information these tracts contain. 
highlight the Society's achievements and bolster internal morale, a degree of optimistic exaggeration was an intrinsic feature.

As for the narratives which travelled the channels of the Catholic underground, these too are fraught with methodological pitfalls. In an environment where clerical manpower was severely limited, Tridentine missionaries were obliged to rely on the written word as a kind of 'dumb preacher'. ${ }^{9}$ Endorsing fundamental Catholic precepts and practices which had been abolished with the advent of Protestantism, many reports celebrating the heroic lives and deaths of martyred priests and recusants must be recognized as surrogate and supplementary instruments of indoctrination and instruction. Others emanated originally from the pens of literate lay people, but in the long run all were afflicted by a familiar process of hagiographical accretion. Products of negotiation between the needs and beliefs of the beleaguered laity and the moral and ideological preoccupations of the clergy who served them, they grew and mutated each time they were recounted or copied. Gradually transforming themselves into a body of consoling and edifying legend, they were eventually absorbed into the collective social memory of the English Catholic community. Collated and sifted by the penitentiary Christopher Grene in the I67os and 8os, many of these accounts were distilled into print by Bishop Richard Challoner fifty years later in his Memoirs of missionary priests. ${ }^{\mathbf{1 0}}$ Like medieval miracle stories, early modern tales of thaumaturgic wonders bear witness to a series of ongoing and intricate dialogues between oral and written culture, official dogma and local custom, and ecclesiastical objectives and lay instincts and opinions. They also testify to competing tendencies and divergent agendas within the ranks of the Counter Reformation priesthood itself. It is probably unwise to try to disentangle too precisely the multiple participating voices in these conversations, but by listening to them carefully we may

9 See my "'Domme preachers? Post-Reformation English Catholicism and the culture of print', Past and Present, I68 (2000), pp. 72-I23.

10 Grene's martyrological Collectanea are preserved at Stonyhurst College, Lancashire, and St Mary's College, Oscott, Sutton Coldfield. Richard Challoner, Memoirs of missionary priests (I74I-2). All subsequent references are to the edition prepared by J. H. Pollen (London, I924). Nineteenth-century editions of these scattered documents were no less martyrological in character. The very title of John Morris's Troubles of our Catholic forefathers (3 vols., London, I872-7) betrays its sectarian intentions; Henry Foley's Records of the English province of the Society of Jesus (7 vols. in 8, London, I877-83) is the work of a Victorian Foxe; and J. H. Pollen's Unpublished documents relating to the English martyrs, I: 1584-1603, Catholic Record Society 5 (London, I908) must be situated within the same canon of sacred commemorative literature. The latter was linked with the postulation for the beatification of the martyrs. Ironically, the apologetic purpose of these later works may have militated against the inclusion of even more material regarding the miraculous. Their editors were often distinctly uncomfortable about incorporating accounts of supernatural phenomena which might appear 'quaint', 'absurd', and 'ridiculous' to the readers of an age which prided itself on its liberal, humanist values and coolly rationalist outlook. The 'nauseous subject' of exorcism was a source of particular embarrassment. See, e.g., Foley, Records, v, p. vi, vII, pt 2, p. vii; Morris, Troubles, II, p. 98; Robert Persons, 'An observation of certayne aparent judgments', ed. J. H. Pollen, in Miscellanea II, Catholic Record Society 2 (London, I906), p. 202; Philip Caraman, ed., William Weston: the autobiography of an Elizabethan (London, I955), p. 29. Francis Edwards edited Henry More's Historia Missionis Anglicanae Societatis Jesu (I66o) so 'that legend is removed and history remains': The Elizabethan fesuits (London, i981), p. x. 
learn much about the latent tensions at the heart of Tridentine Catholicism and about the points of conflict and overlap between pre- and post-Reformation religion. ${ }^{11}$

\section{I}

The central place which belief in the constant intervention of supernatural forces in human affairs occupied in pre-Reformation English religious culture can hardly be doubted. The idea that God performed miracles upon the intercession of saints and in response to vows and promises made by the laity was a vital part of what Bob Scribner labelled the late medieval 'economy of the sacred'. Assumptions about the immanence of the holy in the earthly world sustained a vast repertoire of ritual practices. They underpinned devotion to relics and images, fostered the widespread use (and misuse) of sacramentals, and buttressed the thriving tradition of pilgrimage to prominent shrines. As elsewhere in Europe, fifteenth-century Englishmen and women seem to have displayed an immense appetite for the divine. This was one of the hallmarks of a vibrant and flourishing piety, which, on the eve of the Reformation, as Eamon Duffy has persuaded us, showed little sign of exhaustion, stagnation, or decay. ${ }^{\mathbf{1 2}}$

But it must not be forgotten that there was a strong reaction against the crude materialism which marked some aspects of late medieval Christianity in the circles of early Catholic evangelicals. In the context of Luther's damaging attacks on the cult of saints and its 'superstitious' adhesions, humanist criticism of religious credulity exercised considerable influence. Erasmus's acid satire of popular belief and practice in the Colloquies found much sympathetic support and Juan Luis Vives's merciless assault on the miracle-laden Golden legend as a book written by men 'with mouths of iron and hearts of lead' was likewise widely endorsed. Inaugurating a tradition which reached full maturity in the Protestant polemic already discussed, such writers accused avaricious priests of forging wonders in order to extort from the unwitting populace. In his Dialogue concerning heresies of I 529 ,

11 For discussions of medieval miracle literature in these terms and attempts to resolve the difficult methodological issues, see Aron Gurevich, Medieval popular culture: problems of belief and perception, trans. J. H. Bak and P. A. Hollingsworth (Cambridge and Paris, I988), p. 5 and passim; Julia H. M. Smith, 'Oral and written: saints, miracles and relics in Brittany, c. 850-c. I250', Speculum, 65 (I990), pp. 309-43; Marcus Bull, ed., The miracles of Our Lady of Rocamadour: analysis and translation (Woodbridge, I999), pp. I5-I6, 32-8; Catherine Cubitt, 'Sites and sanctity: revisiting the cult of murdered and martyred Anglo-Saxon royal saints', Early Medieval Europe, 9 (200o), pp. 53-83; C. S. Watkins, 'Sin, penance and purgatory in the Anglo-Norman realm: the evidence of visions and ghost stories', Past and Present, I75 (2002), pp. 3-33.

12 See Keith Thomas, Religion and the decline of magic (Harmondsworth, I973 edn), ch. 2; Ronald C. Finucane, Miracles and pilgrims: popular beliefs in medieval England (London, I977); R. W. Scribner, 'Cosmic order and daily life: sacred and secular in pre-industrial German society', and 'Ritual and popular belief in Catholic Germany at the time of the Reformation', both repr. in his Popular culture and popular movements in Reformation Germany (London and Ronceverte, I987), pp. I-I6, I7-47; Eamon Duffy, The stripping of the altars: traditional religion in England, c. I4OO-c. ${ }_{15} 80$ (New Haven and London, I992), esp. chs. 5,8 . 
Thomas More deplored such vain fabrications as diabolical devices designed to bring true miracles into disrepute and to further infect society with 'mysbyleve and idolatrye'. In the wake of the Henrician campaign to despoil the monasteries and discredit the papacy, the mechanical contraption which moved the eyes and lips of the famous Rood of Boxley, the priest who confessed at Paul's Cross to pricking his fingers while celebrating mass to simulate a bleeding host, and the Dominican friars of Berne burnt at the stake in ${ }^{5} 507$ for feigning a vision of the Blessed Virgin Mary became notorious scandals, paradigms of popish deceit. ${ }^{13}$ Reflecting a mood of evangelical renewal infused by a commitment to returning to the pure stream of Scripture, the writings of English Catholic divines of the I540s, 5os, and 6os either made only sparing reference to these contentious features of traditional piety, or remained prudently silent. ${ }^{14}$ On the Continent, conscious of the mockery to which such abuses had already exposed them, the Catholic reforming initiatives which predated Trent were marked by attempts to restrain the insatiable hunger for miracles and signs displayed by the laity and to wean them away from practices which smacked of witchcraft and paganism. This sense of vulnerability manifested itself in a 'crisis of canonization', a hiatus in saint-making which lasted from ${ }_{5} 523$ until I588. Thereafter the newly instituted Congregation of Sacred Rites and Ceremonies centralized and tightened the process of defining the sacred and shifted emphasis away from spectacular thaumaturgy towards heroic virtue and exemplary zeal. ${ }^{15}$ A further expression of Erasmian caution may be found in the attempt to remodel hagiography as historical biography and to rid traditional vitae of corruptions and impurities. The culmination of this concern for authoritative testimony and scholarly rigour was the ambitious project to edit the Acta sanctorum begun by the Flemish Jesuit Herbert Rosweyde and continued (more famously) by Jean Bolland and his disciples. ${ }^{16}$

${ }^{13}$ See 'The shipwreck', 'The apparition' and 'The religious pilgrimage', in The Whole Familiar Colloquies of Desiderius Erasmus, trans. Nathan Bailey (London, I877); The dialogue concerning heresies, in The complete works of St Thomas More, vi, pts I and 2, ed. Thomas M. C. Lawler et al. (New Haven and London, I98I), bk I, chs. I4-I5. For Vives, see Simon Ditchfield, Liturgy, sanctity and history in Tridentine Italy: Pietro Maria Campi and the preservation of the particular (Cambridge, I995), p. II9. On the Rood of Boxley, see Peter Marshall, 'The Rood of Boxley, the Blood of Hailes and the defence of the Henrician Church', Fournal of Ecclesiastical History, 46 (I995), pp. 689-96; for the simulated bleeding host, see H. G., A gagge for the pope (London, I624), p. 50; for the Berne incident, More, Works, vi, pp. 88-9, 627. For a fuller discussion, see Peter Marshall, 'Forgery and miracles in the reign of Henry VIII', Past and Present, I78 (2003), pp. 39-73.

14 See Lucy E. C. Wooding, Rethinking Catholicism in Reformation England (Oxford, 200o), pp. II6-17, I77.

15 See Peter Burke, 'How to become a Counter Reformation saint', in Kaspar von Greyerz, ed., Religion and society in early modern Europe, I5OO-I80o (London, I984), pp. 45-55 and Hsia, World of Catholic Renewal, ch. 8.

16 See Eric Suire, La sainteté française de la Réforme catholique (XVIe-XVIIIe siècles) (Bordeaux, 200I), pp. 28-30; Ditchfield, Liturgy, sanctity and history, ch. 4, and idem, 'La santità e il culto dei santi fra universalità e particolarismi' (forthcoming). I am grateful to the author for allowing me to read this in advance of publication. 
These continued to be important threads in the fabric of the Catholic revival but it needs to be stressed that the summoning of the Council of Trent coincided with a lively reassertion of the Church of Rome as a repository of numinous power. In its decree of ${ }_{15} 6_{3}$, the Council ordered the eradication of all 'superstition' associated with pilgrimages, images, and relics but vigorously reaffirmed the value of venerating and invocating the saints and their remains and representations. ${ }^{17}$ As Euan Cameron has emphasized, Tridentine Catholicism did not reject the principle that words, symbols, and objects could be receptacles of the divine: it simply sought to bring these resources under closer clerical control and ensure that the priesthood maintained exclusive rights to their application and use. ${ }^{18}$ Paul V's Rituale Romanum contained blessings for vines and a form of exorcism for driving off thunder and the spontaneous cults which sprang up around figures like Francis Xavier, Ignatius Loyola, and Philip Neri were condoned if not encouraged by the papal and episcopal hierarchy prior to their formal beatification. In the 1620 , for instance, the ecclesiastical authorities sanctioned the resort of pilgrims to the shrine of the recently deceased Bishop Francis de Sales, permitting them to touch rosaries and linen cloths to his coffin and carry away fragments of stone scraped from his tomb. ${ }^{19}$ Carefully authenticated accounts of the wonders worked by these holy persons circulated alongside revised versions of the lives of the medieval saints like those prepared by Laurentius Surius and Luigi Lippoman. Many pious falsehoods were excised from these new editions, but as Protestant polemicists like George Abbot were quick to point out, they still contained a vast mass of miracles. ${ }^{20}$ And in his mighty defence of Catholic theology against the onslaughts of the reformers, the Disputationes ... de Controversiis Christianae Fidei (1586-93), Cardinal Robert Bellarmine declared that visible signs were necessary to confirm Christ's Church and endorse any 'extraordinary mission' it launched. ${ }^{21}$

Vigorous rejection of the Protestant precept that miracles had ceased also became an increasingly prominent feature of English Catholic polemic in the course of Elizabeth's reign. In A fortresse of the faith ( $\left.\mathrm{I}_{5} 65\right)$, the Louvain exile

${ }^{17}$ H. J. Schroeder, ed., The canons and decrees of the Council of Trent (Rockford, IL, I978), pp. 215-17. See also the endorsement of these practices in the Jesuit 'Rules for thinking with the Church', in John C. Olin, ed., The Catholic Reformation: Savonarola to Ignatius Loyola (New York, I992).

${ }^{18}$ Euan Cameron, 'For reasoned faith or embattled creed? Religion for the people in early modern Europe', Transactions of the Royal Historical Society, 6th ser., 8 (1998), pp. 165-87.

19 Martin D. W. Jones, The Counter Reformation: religion and society in early modern Europe (Cambridge, I995), pp. II9, I2I. Francis de Sales was not canonized until I665.

${ }_{20}$ Ditchfield, Liturgy, sanctity and history, pp. 124-5. In The reasons which Doctor Hill hath brought, for the upholding of papistry ... unmasked (Oxford, I604), pp. 258-9, George Abbot spoke of the continuing presence of miracles as 'baggage rotten stuffe' and 'dunghill ragges'. See also Joannis Majoris, Magnum speculum exemplorum (Douai, I605), a Jesuit-revised collection of exempla. As William Crashaw remarked in The sermon preached at the Crosse, Feb. xiiij I607 (London, I608), pp. I55-6, this too retained many 'impious and ridiculous Legends' and 'impossible tales'.

${ }^{21}$ Robert Bellarmine, Disputationes ... de Controversiis Christianae Fidei (Ingolstadt, 3rd edn, I590-3), bk 4, ch. I4, n. II (cols. I347-54). See also the strong affirmation by Louis Richeome, Trois discours pour la religion catholique: des miracles, des saincts, et des images (Bordeaux, I597). 
Thomas Stapleton had declared that the working of wonders was a chief means by which God had validated the Roman faith at the time of its very first planting and taunted his upstart Protestant enemies for their inability to cite equivalent 'tokens of their Apostleship'. But, in keeping with the dominant climate of discreet circumspection, he was distinctly defensive about claiming that this gift and grace continued to differentiate the true religion from its false and diabolical rivals and to mark out the chosen messengers of the Almighty from spurious prophets, making the point only implicitly. ${ }^{22}$ Published a decade later in I574, however, Richard Bristow's portable manual of 'motives' indexed a new spirit of neo-scholastic defiance. It insisted emphatically upon the perpetuity both of 'dogmaticall miracles' wrought in support of disputed doctrines and of 'personall miracles' performed through the agency of individual people and listed visions and prophecies as other instruments by which the Lord vindicated points in controversy, approved 'innumerable Holy Persons of our communion', and showed his followers the way to salvation. ${ }^{23}$ Writing in 1600 , the Benedictine Thomas Hill likewise cited the unbroken chain of supernatural acts from the first century AD as proof that Roman Catholicism was the sole possessor of truth. ${ }^{24}$ Miracles, declared Robert Chambers in a tract of 1606 , had not only been necessary to persuade the Jews and Gentiles to embrace Christianity while it was still in its infancy; they remained a critical aid to converting the heathen and infidel peoples of the New World and the Far East, combatting the atheism and impiety which plagued contemporary Europe, and confounding the hostile heretics by which English Catholics were surrounded. In the midst of the 'horrible hurliburlies' of the present age, it was hardly likely that the Lord would abandon such a powerful mechanism for comforting the faithful and confirming his persecuted Church. Those both 'of ancient and fresh memory', the Jesuit John Floyd told his Protestant opponents in $\mathrm{I}_{6} \mathrm{I} 3$, were 'thunderclapps that shake the foundations of your Ghospell'; according to George Musket and others the absence of 'heavenly testifications and impressions of the soveraine hand of the Almighty' was clear evidence that Protestantism was 'the conventicle of Satan ${ }^{25}$ Miracles were held to be superior even to Scripture itself as a witness to

22 Thomas Stapleton, A fortresse of the faith first planted amonge us Englishmen (Antwerp, I565), part 2, ch. 3 , fos. $97 \mathrm{a}-99 \mathrm{~b}$. See also his preface to The historie of the Churche of Englande: compiled by Venerable Bede (Antwerp, 1565), pp. $4^{-8}$, in which he turns the charge of fabrication back against the Protestants, pouring scorn on the 'miserable miracles' which filled the pages of Foxe's 'Book of Martyrs'. As Peter Marshall notes, in the early Elizabethan period there was a similar wariness about citing ghosts as proof of the existence of purgatory: Beliefs and the dead in Reformation England (Oxford, 2002), p. 242.

${ }^{23}$ Richard Bristow, A briefe treatise of divers plaine and sure waies to finde out the truth (Antwerp, I574; repr. I599) (hereafter Motives), fos. I5a-39a. This was summarized in his Demaundes to be proponed of Catholiques to the heretikes (Antwerp, I576). See also Wooding, Rethinking Catholicism, pp. 263-4.

24 Thomas Hill, A quartron of reasons of Catholike religion (Antwerp, I6oo), pp. 33-9.

25 Philips Numan, Miracles lately wrought by the intercession of the Glorious Virgin Marie, at Mont-aigu, nere unto Sichem in Brabant, trans. Robert Chambers (Antwerp, I6o6), dedication to James I, esp. sigs. $\mathrm{B}_{\mathrm{IV}}-\mathrm{B}_{4} \mathrm{v}$, quotation at sig. B3v; John Floyd, Purgatories triumph over hell (n.p., I6I3), p. I45 and ch. 5 passim; Numan, Miracles, p. 269; George Musket, The bishop of London his legacy (St Omer, I623), 
the veracity of doctrine and practice. Every sect could wrest the biblical text to its advantage, said the Irish Jesuit Richard Archdekin in I667, but when the Lord 'speakes by works ... they cannot be controverted' ${ }^{26}$ It was in this sense that Catholic writers spoke of miracles as the 'very woord' and 'divine sentence' of God. As Edward Worsley wrote in reply to the Restoration bishop Edward Stillingfleet, these were His 'legible Characters' and 'Seals and Signatures of truth'. ${ }^{27}$

Nevertheless, as we shall see, throughout the period in question Counter Reformation writers had to tread a perilous tightrope: miracles were a powerful weapon in the crusade against Protestantism, a religion which publicly repudiated the possibility that this category of supernatural events had continued into modern times, yet they could also backfire badly against them, laying the Roman Catholic faith open to savage ridicule and sarcasm.

\section{I I}

Spirited defence of the miraculous against Protestant attacks was accompanied by active efforts to publicize both foreign and native modern examples. Richard Bristow related the case of Margaret Jessop, a crippled Englishwoman living in Brussels cured in 1573 because of her pious devotion to three bleeding hosts preserved in the city church of St Gudila. ${ }^{28}$ In the same year there were reports that an ominous vision of Atlas bearing the world on his weary shoulders had been seen near Montpellier in France, above 'a place whereat the hugenotes were woonte to have theyre sermones'. ${ }^{29}$ Some 700 broadsheets about the Belgian marvel were intercepted by English customs officials in $1584^{30}$ and engravings of other miracles wrought by the Blessed Sacrament in Flanders seem to have been shipped over from the Continent in large quantities. Whenever one came into the hands of Edward Throgmorton in Worcestershire, he seized the opportunity to show it to his companions and urge them to forsake the 'fables and lies' of the heretics. ${ }^{31}$ The early seventeenth century saw the translation of a major collection of thaumaturgic wonders worked by the Virgin Mary at the chapel shrine at Mont-aigu near Sichem in Brabant assembled by the town clerk Philips Numan. Like two similar anthologies published by the humanist Justus Lipsius in Latin, Numan presented his catalogue of carefully attested cures as evidence of divine approbation for the cult of saints and as a sign that God would 'very soon [remove] the scourge of his ire and indignation' from the Netherlands. In turn Richard

\footnotetext{
pp. 64-76, at p. 65. For further discussion of the controversy over miracles, see D. P. Walker, 'The cessation of miracles', in Ingrid Merkel and Allen G. Debus, eds., Hermeticism and the Renaissance: intellectual history and the occult in early modern Europe (Washington, London, and Toronto, I988), pp. I I I-24.

26 Richard Archdekin, A treatise of miracles (Louvain, I667), p. 9; Numan, Miracles, sig. B7v.

${ }^{27}$ Numan, Miracles, sig. A4r; Edward Worsley, A discourse of miracles wrought in the Roman Catholick Church (Antwerp, I676), sig. b2v, p. 4. $\quad{ }_{28}$ Bristow, Motives, fos. I9a-27a.

29 British Library, Cotton MS Vespasian A-xxv, fos. $4 \mathrm{Ir}-42 \mathrm{~V}$, at fo. $4 \mathrm{IV}$.

30 British Library, Lansdowne MS 42, fo. I74r. $\quad{ }_{31}$ Foley, Records, IV, p. 293.
} 
Chambers hoped they would offer solace to his afflicted co-religionists in England. ${ }^{32}$

Other clerical exiles furnished their countrymen with vernacular editions of the Marian miracles associated with the Holy House of Loreto near Ancona, which had allegedly flown there from Nazareth in the late thirteenth century. ${ }^{33}$ In I6r6, Pedro de Ribadeneira's Life of Ignatius Loyola was first published in English, replete with many posthumous wonders reported to have been done by the Jesuit's relics, vestments, and other possessions, as well as by portraits and by slips of paper bearing his subscription. Ribadeneira's accounts of people restored to perfect health, delivered from demons, and assisted in childbirth by the intercession of this holy father came from Italy, Spain, Germany, Hungary, and the East Indies. ${ }^{34}$ The theater of Japonia's constancy ( 1624 ) incorporated a fresh batch of prodigies achieved by vows, novenas, and prayers to an icon of the newly canonized saint in the kingdom of Aragon, as well as cures achieved by use of the oil burning in the lamp before it and of the liquid it sweated when it was placed on the altar. Similar stories filled the pages of Orazio Torsellino's biography of Francis Xavier, translated in 1632 , and thirty-five years later Richard Archdekin supplemented a long list of miracles associated with his relics at Mecklenberg with compelling examples from Dublin, Waterford, Kilkenny, and Ross. ${ }^{35}$ News of these and other wonders was also transmitted orally: one case widely publicized by the priests of late Jacobean London concerned a Carmelite friar in Paris who, like the Italian Oratorian Philip Neri, levitated daily while elevating the host. In I62I he was reported to have prophesied that within two years there would not be a single heretic remaining in France. ${ }^{36}$

But English Catholics had no need to turn to Europe, America, or Asia to prove that miracles on behalf of their faith continued in perpetuity. Their own country was yielding an equally rich harvest of astonishing marvels. A vast number of these were linked with the Elizabethan and early Stuart martyrs. As Anne Dillon has shown, in the official, formal texts about their deaths prepared

${ }^{32}$ Numan, Miracles, p. 20; Justus Lipsius, Diva Virgo Hallensis: beneficia eius et miracula fide atque ordine descripta (Antwerp, I6o4); idem, Diva Sichemiensis sive Aspricollis: nova eius benficia et admiranda (Antwerp, I605).

${ }^{33}$ Orazio Torsellino, The history of our B. Lady of Loreto, trans. Thomas Price ([St Omer], I6o8), esp. bk I, chs. I5, I7, bk 2, chs. I, 2, 7, I0, bk 3, chs. I3-I8, 24-33, bk 4, chs. 4-12, I7-2I, 26-30. See also Antonio Daza, The historie, life, and miracles, extasies and revelations of the Blessed Virgin, Sister Foane, of the Crosse, of the third order of our Holy Father S. Francis, trans. Francis Bell (St Omer, I625), chs. I I-I3, 20 and passim.

34 Pedro de Ribadeneira, The life of the Holy Patriarch S. Ignatius of Loyola, author, and founder of the Society of Jesus, trans. S.J. [M. Walpole] ([St Omer], I6 6 ; г 622 ).

35 The theater of Japonia's constancy, trans. William Lee ([St Omer], I624). This included 'A briefe Relation' of miracles worked by Ignatius at Munebrega in Spain. Orazio Torsellino, The admirable life of S. Francis Xavier, trans. Thomas Fitzherbert (Paris [St Omer], I632), esp. bk 2, chs. 7, I6, bk 3, ch. 7 , bk 4 , ch. 3 , bk 6, chs. I-4; Archdekin, Treatise of miracles. This latter tract was intended primarily for the Irish market.

${ }^{36}$ Gee, Foot out of the snare, ed. T. H. B. M. Harmsen (Nijmegen, I992), p. I36; British Library, Stowe MS i76, fo. 207 r. 
for public consumption, clerical writers were decidedly wary about including spectacular examples of the miraculous. Adamant that outward signs were superfluous testimonies to the martyrs' sanctity, they meticulously censored sensational details which might provoke a fresh wave of scoffing Protestant attacks on 'popish credulity'. The versions which disseminated among the lay people to whom they ministered in England, however, displayed no such restraint. Full of signs and wonders of a highly traditional kind, some of them would fit more comfortably between the covers of the Golden legend than of the humanist-inspired hagiographies of the sixteenth and seventeenth centuries. Synthesizing rumour and hearsay with biblical symbols and medieval motifs, they constructed the victims of the Elizabethan and early Stuart treason laws in the mould of the courageous saints of old, presenting their heroism as an imitation of the redeeming passion of Christ. ${ }^{37}$ Many manuscript accounts, for instance, told how the disembowelled bodies of the martyrs had cried out, sat up, or defied physical decomposition. Alexander Briant's mangled corpse was said to have lifted itself from the block and Edmund Genings prayed to St Gregory even as the hangman was removing his entrails. ${ }^{38}$ Robert Southwell's holy heart leapt in his executioner's hands in 1596 and the pathetically crushed body of the Yorkshire matron Margaret Clitherow showed no signs of putrefaction after six weeks. ${ }^{39}$ The indestructability of the martyrs' remains was matched by their extraordinary immunity to capture. Father Scroop became invisible to the pursuivants who burst into a gentleman's house to apprehend him, the door of a bolted chamber in which Robert Parsons was imprisoned flew open three times, and the leg irons restricting the recusant John Rigby likewise fell off miraculously. ${ }^{40}$ Future martyrs were often honoured with dreams and premonitions of their sacrificial deaths and seen surrounded by haloes on the night before being conveyed to the gallows. A bright light like a ray of glory emanated from Robert Watkinson as he celebrated his very last mass and Christopher Bayles perceived the shadow of a diadem hovering over him as he sat with a candle in his dark, filthy dungeon on the eve of his martyrdom. ${ }^{41}$ Other strange happenings signalled God's favour towards his faithful servants. Mimicking the aberrations of nature which had accompanied Christ's crucifixion, the Thames stood still on the day Edmund Campion made the ultimate sacrifice, horses refused to drag the hurdle bearing

\footnotetext{
37 See Anne Dillon, The construction of martyrdom in the English Catholic community (Aldershot, 2002), ch. 2. On manuscript accounts of the martyrs, see also Arthur F. Marotti, 'Manuscript transmission and the Catholic martyrdom account in early modern England', in idem and Michael D. Bristol, eds., Print, manuscript, and performance: the changing relations of the media in early modern England (Columbus, OH, 200o), pp. I72-99, esp. I87-90. In his printed account of the execution of Everard Hanse, The copie of a double letter ([Rheims, I58I]), Robert Persons, for instance, declared 'we neede no miracles to trye Martyrs' (p. 5). See the similar conclusions of Marshall, Beliefs and the dead, pp. $242^{-}-5$.

${ }^{38}$ Challoner, Memoirs, p. $3^{8}$; Foley, Records, IV, p. 367. John Genings, The life and death of Mr Edmund Geninges Priest (St Omer, I6I4), p. 85.

${ }^{39}$ Foley, Records, I, p. 375; 'An ancient editor's notebook', in Morris, Troubles, III, p. 52.

40 Gee, Foot out of the snare, p. I37; Challoner, Memoirs, p. 242.

41 Challoner, Memoirs, p. 265; Foley, Records, I, p. 326.
} 
Edward Waterson through the streets to his place of execution in I593, and the sea near Penzance assumed the colour of blood on the day two priests suffered in July I6r2. ${ }^{42}$ Similarly, animals grazing in the courtyard of a house at Hislip refused to eat or step on a crown of grass which sprang up near the spot where Henry Garnet and Edward Oldcorne were arrested in I6o6. ${ }^{43}$

The pious embellishments which accounts of the martyrs acquired as they circulated around the Catholic community clearly owed much to the lay people by whom they were lovingly retold but the Jesuits and seminary priests energetically deployed them to teach lessons about the virtues of recusancy and the sacred powers of the priesthood. They used them to stress the glorious rewards won by men and women who resisted the temptation to bow to Baal, attend Protestant services, and partake of Calvin's impious supper. In defiance of the reformers' claim that every believer was his own intercessor, they depicted the Catholic clergy as a consecrated caste through whom the Almighty uniquely mediated His saving grace. This process is particularly transparent in a 'Catalogue of Martyrs' assembled by John Gerard around 1594, which told how Robert Sutton's quarters were taken down from display in Stafford 'all consumed to the bones', except for his right index finger and thumb, which remained mysteriously intact - those parts of his hand constantly hallowed by contact with the transubstantiated bread and body of Christ. ${ }^{44}$ The English Catholic missionaries deliberately fostered the cults of these saints in waiting, collaborating in a process of spontaneous beatification by popular acclamation which ironically ran counter to the attempts of the Tridentine Church to regulate and centralize the procedures for sanctification. Here, as in Ireland and Holland, lay initiative continued to play a prominent part in the creation and veneration of new members of the company of heaven. It was not until 1970 that the papacy rendered them fully legitimate by formal canonization. ${ }^{45}$

Providential judgements visited upon persecutors were another aspect of the miraculous which the missionaries pressed into the service of casuistical instruction and confessional propaganda. Part of a tradition stretching from Eusebius's Ecclesiastical history to Foxe's Actes and monuments, such anecdotes graphically illustrated divine anger at those who imbued their hands in the blood of the

42 Foley, Records, III, p. 623; Pollen, ed., Unpublished documents, p. 23I; Challoner, Memoirs, p. I87; Michael Questier, ed., Newsletters from the archpresbyterate of George Birkhead, Camden Society, 5 th ser., I2 (I998), pp. I88-9.

${ }_{43}$ Foley, Records, IV, p. I25; Stonyhurst College, Lancashire, MS A. IV. 7, no. 5.

44 Stonyhurst College, Lancashire, MS Anglia vii, n. 26, printed in Pollen, ed., Unpublished documents, p. $29 \mathrm{I}$.

${ }^{45}$ Gillespie, Devoted people, p. 69; Frijhoff, 'La function du miracle', p. I72 and passim; Brad S. Gregory, Salvation at stake: Christian martyrdom in early modern Europe (Cambridge, MA, I999), pp. 30I-5. Surprisingly few Counter Reformation martyrs were canonized in the seventeenth or eighteenth centuries, as Burke notes, 'How to become a Counter-Reformation saint', p. I39. Hsia, World, p. I25, suggests that martyrs were ill-suited to the self-image of a Church which sought to present itself as triumphant and militant. In the context of England, the canonization of convicted traitors would also have been politically insensitive, not to say provocative. 
martyrs. ${ }^{46}$ Thus Sir Henry Yelverton, who presided over the trial of the Jesuit Edmund Arrowsmith in I628 and ghoulishly watched his execution through a telescope, was said to have been struck by an insensible blow which carried him straight to his grave. In the middle of reading the indictment against Richard White, a Welsh schoolmaster who had disrupted a Protestant service by rattling his shackles, the clerk of assizes was rendered temporarily blind, while the constable who arrested William Davies in I593 was seized by an inflammation of his right toe which eventually overtook his entire body, exuding a horrible smell. ${ }^{47}$ Robert Barrett reported several 'extraordinary examples' of 'avenging justice' to the rector of the English College at Rome in I584, including the case of Thomas Norton, 'rackmaster and torturer in chief' of Edmund Campion. ${ }^{48}$ Like the exempla with which medieval friars and parish priests enlivened their sermons, these stories frequently contained telling echoes of Scripture. Callous betrayers were implicitly assimilated with Judas and the punishments suffered by intolerant magistrates often corresponded with the penalties meted out in the Old Testament to those who had molested God's chosen people, the Jews. Sometimes entire communities were deemed to have been the target of supernatural retribution. Nicholas Sander, Robert Persons, and the Spanish Bishop Yepez of Taraçona all attributed a major outbreak of gaol fever in Oxford in 1577 to God's wrath at the trial of the recusant bookseller Rowland Jenkes, and the epidemic of plague which devastated Dorchester in I594 was widely interpreted as vengeance for the death of Father John Cornelius. ${ }^{49}$

Other enemies of the Catholic faith also felt the avenging hand of the Almighty upon them, particularly puritan zealots obsessed with eradicating all traces of popish idolatry. One story which circulated orally and scribally in the West Midlands towards the end of Elizabeth's reign told of the untimely demise of a dedicated iconoclast, 'one Mutton, sometime sheriff of Chester, [who] had no greater felicity than in the breaking of crosses and chalices', ${ }^{50}$ while the Jesuit John Gerard recorded the sobering tale of a disbelieving Protestant visitor paralysed after deliberately polluting the sacred waters of the spring with his dirty boots. ${ }^{51}$ Parallelling other parts of Europe where the Reformation was

46 See my Providence in early modern England (Oxford, I999), ch. 2, for this tradition.

47 Challoner, Memoirs, p. 372; Foley, Records, II, p. 53 (Arrowsmith); Challoner, Memoirs, p. Io3; Richard Simpson, 'A true report of the life and martyrdom of Mr Richard White, schoolmaster', The Rambler, 3 rd ser., 3 (I860), p. 239 (White); Challoner, Memoirs, p. I96 (Davies).

${ }^{48}$ P. Renold, ed., Letters of William Allen and Richard Barret, 1572-I598, Catholic Record Society $5^{8}$ (London, I967), pp. 96-9.

49 For Jenkes, see the account in my Providence, pp. 234-5, and the references cited therein. For Cornelius, see Challoner, Memoirs, pp. I98-20i.

50 'An ancient editor's notebook', in Morris, Troubles, III, p. 59. This is probably a reference to Edward Button, mayor of Chester in I6ı6: see Lawrence M. Clopper, ed., Records of early English drama: Chester (Manchester, I979), pp. 306, 526.

${ }^{51}$ John Gerard, The autobiography of an Elizabethan, ed. Philip Caraman (London, 1951), p. 47. For another version of this story, see Albert J. Loomie, ed., Spain and the facobean Catholics, II: $1613-1624$, Catholic Record Society 68 (London, I978), pp. I39-40. 
accompanied by a violent assault upon traditional symbols of supernatural power, the underlying theme of such punitive miracles was the capacity of desecrated images, statues, and shrines to fight back against brutal attacks. ${ }^{52}$ Others defended solemn observance of the Catholic calendar. According to the district report of the Jesuit mission in Lancashire and Staffordshire for I623, a hot Protestant widow who habitually profaned holy days by carrying out her everyday work was providentially chastised when her house caught fire on the feast of St Andrew and was nearly razed to the ground. ${ }^{53}$ As these cases reveal, it would be a mistake to ascribe the diffusion of accounts of the miserable ends of prominent heretics solely to the Catholic laity. Narratives of divine justice were clearly joint creations. Here, as elsewhere, we may detect the heavy hand of clerical intervention shaping them to serve as warnings about the dangers of sacrilege.

If these cautionary tales were designed to dint Protestant pride and inflame Catholic zeal, others were employed to remind the laity of the dangers of schism and spiritual frailty. Stories about church papists who suffered psychological anguish or were otherwise punished for entering Anglican temples could be a highly effective aid in the missionary campaign to eliminate the cancer of conformity. In the memoir he wrote for the benefit of novice priests in the seminaries, William Weston remembered the searing thirst which overtook the Norfolk gentleman Francis Wodehouse when he defied his conscience and attended a Protestant service. An anecdote preserved by the Jesuits of the Worcester and Warwickshire district in ${ }_{1} 636$ as 'a salutary warning to all similar offenders' concerned a wealthy schismatic who fell down the stairs, fatally breaking his neck. ${ }^{54}$ Other episodes revealed the risks of eating meat during Lent and ignoring the directions of priests. In The foot out of the snare ( 1624$)$, John Gee sniggered at the story of Katherine Riland of London who choked consuming a morsel of flesh forbidden by her ghostly father, dismissing it as an amusing popish fiction, but it finds more than one analogue in the pages of Jesuit internal memoranda. ${ }^{55}$ A woman who omitted to mention a grave sin during confession was tormented by a vision of reptiles crawling in and out of her mouth and a soldier from Hampshire who reviled St Ignatius with blasphemous curses was instantly afflicted with an excruciating disease of the bowels and intestines. ${ }^{56}$ Such examples reflect the skill with which the clergy could transform local tragedies into moral exempla. In this way, miracles became catechetical tools, opportunities for educating lay people in the ideals of Tridentine piety as well as impressing

${ }^{52}$ See Frijhoff, 'La function du miracle', p. I77; Greengrass, 'Peregrinations', pp. 405-7. In southwestern Germany, images desecrated by Protestant soldiers during the Thirty Years War likewise became the subject of legends of prodigious weeping, sweating, and bleeding. See Forster, Catholic revival, pp. 90-I.

${ }^{53}$ Foley, Records, vII, pt 2, p. II

${ }^{54}$ Weston, Autobiography, ed. Caraman, pp. I49-5o; Foley, Records, vII, pt 2, p. II39.

${ }^{55}$ Gee, Foot out of the snare, ed. Harmsen, p. I37.

${ }^{56}$ Foley, Records, vII, pt 2, p. II 35 ; III, p. 39I. Robert Persons also compiled a catalogue of judgements on 'divers fautors of that faction' which opposed the Society of Jesus: 'Observations of certayne aparent judgments', ed. Pollen, p. 203. 
upon them God's hatred of heresy. How far the Catholic faithful internalized the Counter Reformation lessons enshrined in these oral and scribal texts remains, of course, a rather moot point. Without the reinforcement of regular priestly contact and guidance, it is probable that they did so only imperfectly.

\section{V}

More positive proof that the Church of Rome was a designated channel of supernatural power came in the guise of thaumaturgic wonders worked through the medium of material objects. Some parts of Europe reclaimed from Lutheranism and Calvinism in the course of the seventeenth century had to import relics to replace the casualties of Reformation iconoclasm. In the Upper Palatinate, for instance, skeletons of the early Christian martyrs translated from the newly discovered Roman catacombs became fresh foci for Catholic piety in the wake of Maximilian I's annexation of the formerly Protestant territory in I62 I ${ }^{57}$ English Catholicism, however, had no trouble filling the void left by the holocaust of holy items launched by Henry VIII and Thomas Cromwell in the I530s. The mortal remains of the martyrs quickly compensated for the loss of the sacred body parts of medieval saints like Thomas Becket. As early as I572, one William Tessimond was hauled before the High Commission in York for possessing hair from the beard of the disgraced earl of Northumberland which he had cut off while the Northern Rebel's head was displayed in the tollbooth. ${ }^{58}$ The death of Cuthbert Mayne in 1577 marked the beginning of a new traffic in relics. Every execution saw sympathetic spectators scramble to dip handkerchiefs and gloves in blood, rescue scraps of bone, muscle, and flesh, and gather up the discarded clothes and possessions of their heroes. A young man present at Thomas Atkinson's martyrdom in I6ı 6 purchased his stockings from the hangman and onlookers eagerly gathered up Hugh Green's crucifix, rosary beads, book of litanies, spectacles, and priest's girdle at Dorchester in $1642^{2} .^{59}$ Other souvenirs included the chalices which the missionaries had used in their last mass, the ropes with which they were hanged, and the bloodied aprons and sleeves of their executioners. Among the items preserved at the English College at Valladolid was 'a piece of old Tyburne', the scaffold upon which so many members of the Society of Jesus had died, and the head of John Cornelius was discovered in a cupboard by workmen clearing rubbish after the Great Fire of London in $1666 .{ }^{60}$

\footnotetext{
57 See Trevor Johnson, 'Holy fabrications: the catacomb saints and the Counter Reformation in Bavaria', Journal of Ecclesiastical History, 47 (1996), pp. 274-97.

58 Borthwick Institute of Historical Research, York, High Commission Act Book I572-4, fo. 4or--v.

59 Challoner, Memoirs, pp. 34I, 423.

60 Ibid., pp. 464, 556; Foley, Records, I, p. 565; Lewis Owen, The running register: recording a true relation of the state of the English colledges, seminaries and cloysters in all forreigne parts (London, I626), p. 54; Foley, Records, vI, p. 680 .
} 
Sometimes the very acquisition of such relics was itself regarded as miraculous. The handkerchief used to rake William Ward's heart out of the ashes did not burn and the thumb with which Edmund Genings had consecrated the host came away when touched by a pious virgin at Newgate. ${ }^{61}$ Yet more famously, an ear of straw soaked with the blood of the Gunpowder Plot martyr Henry Garnet jumped into the hand of John Wilkinson as he stood beneath the gallows. Within a few days a perfect effigy of the Jesuit appeared on one of the husks, evoking much mockery from Protestants, who alleged it was the work of an ingenious engraver, and much admiration from Catholics, who heralded it as a divine token of Garnet's innocence of the heinous crime of treason. The very sight of it was said to have made 500 converts. ${ }^{62}$ Like the corpses of medieval saints, the dismembered remains of early modern martyrs were often reputed to have discharged a fragrant perfume before being removed for embalming. Imitating traditional icons, a picture of Christ's Nativity that Father Peter Wright gave to a lady who visited him in prison became spotted with blood on the first anniversary of his death. ${ }^{63}$ The presence in such accounts of so many 'secondary' or 'associative' relics is indicative of the disorderly multiplication of holy objects which seems to have been a feature of this context. In Tridentine Europe the authentication, transportation and display of relics was subject to unprecedented regulation $;^{64}$ in Protestant England it was impossible for the Counter Reformation clergy to exercise anything like the same degree of control over their distribution and use. It may be argued, moreover, that the Jesuits and secular priests did less to restrain the fervent desire of the recusant laity to obtain these sacred deposits than they did to encourage it. The unruly expansion of the relic trade was perhaps a small price to pay for the flourishing cults of their heroic dead colleagues. The particular circumstances of the English mission appear to have given additional impetus to the strategy of catering for popular thirst for the sacred employed by Counter Reformation evangelists on the European mainland.

Priests were also active in advertising the extraordinary cures worked by martyrs' relics. The Jesuit Annual Letters contain many examples of individuals released from dangerous illnesses by the application of these blessed remnants, as do the martyrological accounts which they copied, collected, and eventually published. The relics of John Southworth were said to have resuscitated Francis Howard, and pieces of the flesh of Thomas Garnet laid on the breast of William Atkinson did the same after physicians had relinquished all hope of

${ }^{61}$ Challoner, Memoirs, pp. 390-2; Geninges, Life, pp. 93-4.

${ }^{62}$ For this episode, see Foley, Records, IV, pp. I2I-33, I95-20I; British Library, Additional MS 2I, 203, fos. 22r-23r; Stowe MS I69, fo. 27r; and R[obert] P[ricket], The Jesuits miracles, or new popish wonders: containing the straw, the crowne, and the wondrous child (London, I607). See also my Providence, p. 243.

${ }^{63}$ Foley, Records, II, pp. 548-9.

${ }^{64}$ Simon Ditchfield, 'Martyrs on the move: relics as vindicators of local diversity in the Tridentine Church', in Diana Wood, ed., Martyrs and martyrologies, Studies in Church History 30 (Oxford, I993), pp. 283-94; idem, 'La santità e il culto dei santi'. 
saving him. ${ }^{65}$ The cord which had strangled John Kemble cured Captain Scudamore's daughter of a violent sore throat when hung round her neck in the late seventeenth century and the holy hand of Edmund Arrowsmith had remedial effects when stroked down the backs of sick children and adolescents as late as the ${ }^{1760 s} .^{66}$ The recovery of Robert Southwell's sister from a severe ailment after the application of her brother's relics in I635 was considered all the more remarkable because she dissembled her faith and outwardly passed herself off as a Protestant. ${ }^{67}$ In this instance, the didactic gloss with which the clergy so often lacquered these miracle stories is clearly perceptible. Similarly, some underline the need for the patient to repent sincerely and to follow the correct ritual procedures prior to the application of the relic by a priest. In others, by contrast, the success of the cures brought about by fragments of the martyrs is not contingent upon ecclesiastical permission or superintendence: lay people employ them more or less indiscriminately. In these texts, it is tempting to suggest, we are presented with evidence of popular intervention in the construction of these composite narratives.

Complementing the remains of native priest martyrs were the relics of revered foreign Jesuits. A tiny fragment of Ignatius Loyola's winter tunic cured Mary Ward of a lingering consumption in St Omer in I6I4 and twenty years later another religious exile recovered after a relic of Robert Bellarmine was applied to a swelling on his head. The holy articles linked with their founder which the missionaries brought with them to England seem to have been particularly sought after. In I633 one such object was apparently summoned from a distance of eighty miles to assist a noblewoman in childbirth whose life doctors despaired of. ${ }^{68}$ Older relics which had survived the purges of the early Reformation period were also credited with thaumaturgic powers. Pieces cut off from the fragment of the True Cross which continued to be preserved with the Crown Jewels in the Tower of London wrought medical cures for the Yorkshire Catholic Mrs Pudsey and many others in the reign of James I and Charles I. Eighteen youths were cured of smallpox when the rescued arm bone of St Thomas Cantilupe, bishop of Hereford, was exposed during a double octave of prayers and a mass for their recovery. ${ }^{69}$ Even empty reliquaries retained some of the 'holy radioactivity' emitted by the venerated remains they had formerly encased: William Weston recalled how a linen casket saved from Glastonbury Abbey, which had once contained one of the nails that fastened Christ to the Cross, had healed a boy with a penetrating wound in $1586 .{ }^{70}$ Detached from the elaborate shrines in which they had resided in ancient churches and cathedrals, medieval

${ }^{65}$ Challoner, Memoirs, p. 510; Foley, Records, II, p. 497.

${ }^{66}$ Challoner, Memoirs, p. 556; Foley, Records, II, pp. 6I-2.

${ }^{67}$ Foley, Records, I, pp. 375-6. Cf. ibid., vII, pt 2, p. II35, where it is alleged that she was skilled as a physician and applied his relics to her patients.

${ }_{68}^{6}$ Ibid., v, p. 425, VII, pt 2, pp. II9o, II30 respectively. $\quad{ }^{69}$ Ibid., v, pp. 558-9, IV, p. 454.

${ }^{70}$ Weston, Autobiography, ed. Caraman, pp. IIO-II. The phrase 'holy radioactivity' is borrowed from Finucane, Miracles and pilgrims, p. 26. 
relics became part of a large mobile library of miraculous objects. Despite the constant attempts of the missionary priests to reclaim them into the Church's possession, it is apparent that all too many remained in the hands of those who had rescued them from Protestant destruction in the I53os, 40s, and 5os. Preserved for decades in private homes, they too are a testament to the limited ability of the Catholic clergy to patrol the 'gateways of the sacred' in the face of continuing persecution. ${ }^{71}$

The same comments apply to sacramentals, another important component of this portable dispensary of potent religious resources. Both in the literature they produced for reading in recusant households and in their pastoral endeavours in the field, the Jesuits sought to replace traditional amulets with ecclesiastically authorized emblems and talismans. The agnus dei was promoted as a powerful symbol and many shipments of these wax tablets impressed with the Lamb of Christ managed to evade confiscation by port officials, as did consignments of rosaries and medallions linked with newly canonized saints like Francis Xavier, Teresa of Avila, and Philip Neri. The indulgences attached to such objects were vital to devout lay people with only irregular access to priestly confessors who could grant them formal absolution from their sins. ${ }^{72}$ Satisfying the hunger of the populace for healing miracles, these items also became renowned for their therapeutic and prophylactic properties. In I64I, for instance, a small portion of an agnus dei swallowed on the advice of one of the missionary Fathers healed one Suffolk invalid and there were also many reports of barn and house fires extinguished by flinging a particle of it into the flames. ${ }^{73}$ Crucifixes could be equally effective as anti-incendiary devices, as in the case of a blaze which burnt eleven dwellings in Northamptonshire in i626, quenched when a servant of Lord Vaux threw one into its midst. ${ }^{74}$ Other devotional objects were also helpful in defending lay people from assaults by the devil and in counteracting curses and spells. The Annual Letter for $\mathrm{I}_{6} \mathrm{I}_{4}$ boasted that many withered limbs had been restored to full strength and dozens of domestic animals protected from attacks by adepts in the diabolical arts by the use of blessed candles. ${ }^{75}$ As in the rural missions they conducted abroad, the Jesuits in England also propagated their own brand of sacramental - water consecrated by contact with a medal or relic of St Ignatius. In I637, a young woman haunted by spectres was persuaded to sprinkle her bed with Ignatius water before retiring each night and

71 Cf. Gillespie's comments about Ireland in Devoted people, p. I59. For examples of Jesuit attempts to reclaim medieval relics, see Gerard, Autobiography, ed. Caraman, pp. 49-5o; Weston, Autobiography, ed. Caraman, pp. III-I2. For a list of relics in the possession of Anne Vaux and her sister Eleanor Brooksby (including St Stephen's jawbone, a piece of the hairshirt of Thomas Becket, and Robert Sutton's thumb), see Public Record Office (PRO), SP I4/I9/72.

${ }^{72}$ For a list of such items (and associated indulgences) found in the New Prison in March 1622 , see PRO, SP $\mathrm{I}_{4} / \mathrm{I}_{2} 8 / 8$.

${ }^{73}$ Foley, Records, II, p. 567 . For the quenching of fires, see ibid., IV, p. 6I6, VII, pt 2, pp. IIоo, II 36.

74 Trinity College, Cambridge, MS O. 7. 3, fo. 6v. The Protestant writer thought the story fit only to be put 'in their lying log'.

${ }^{75}$ Foley, Records, vII, pt 2, p. I07I. 
soon found herself delivered from these nocturnal terrors. Holy water also had a great capacity for discomfiting heretics: when Widow Wiseman threw some over her enemy Richard Topcliffe, his horse immediately pitched him to the ground. By the later Stuart period, it was being applied to cure all kinds of complaints, including diseases in cattle. ${ }^{\mathbf{7 6}}$ Technically sacramentals did not work ex opere operato but it is clear that the laity often appropriated them as if they were automatically efficacious. Even as they recorded these miracles in the reports they sent to their Continental superiors, the clergy unwittingly revealed evidence of practices which, in the eyes of the Tridentine fathers, verged on 'superstition' and idolatry. No less ironically, the accounts which they circulated to advertise the efficacy of approved types of sacramental may inadvertently have promoted their unauthorized use.

Similar ambiguities surround examples of cures effected by printed books. In I6I5, for instance, a gentleman's son was brought back from death's door when a priest invoked Ignatius Loyola and placed the Rules of the Society on top of his breast. Equally strikingly, in I624 the flow from a burst blood vessel ceased when a copy of Ribadeneira's Life of Loyola was touched to the head of a Catholic physician. By the late i6zos so many wonders had been worked by the book in Lancashire that even illiterate persons had begun to purchase it. ${ }^{77}$ The very texts upon which the missionary clergy relied as locum preachers and teachers could all too easily become the tools of 'a kind of popular Catholic version of the priesthood of all believers' ${ }^{78}$ Where they evaded priestly supervision, devotional objects were prone to be treated as magical charms. ${ }^{\mathbf{7 9}}$

At the same time, we must recognize the capacity of stories about miracles wrought by pious tracts and consecrated items to operate as instruments of confessionalization. In many cases, for instance, a tacit or explicit link was made between the application of a sacred item or liturgical rite and the rejection of schism or heresy. In I6I5 a boy protected from diabolic torment by an amulet sewn into his clothes suffered fresh assaults when it was confiscated by a Calvinist minister. ${ }^{80}$ Twenty years later holy water and an agnus dei cured the wife and children of a blacksmith of a wasting disease, but he himself remained dangerously emaciated after spurning such remedies as 'Papistical figments'. ${ }^{81}$ After witnessing a similar cure in 1636 , a Derbyshire man felt the first stirrings of a desire to embrace Catholicism and heard voices in his sleep threatening him with hell if he failed to abandon the Protestant faith. ${ }^{82}$ According to a late

${ }^{76}$ Ibid., VII, pt 2, p. II4I. See also ibid., II, p. I7, III, pp. I25, 257, v, p. 2I2, VII, pt 2, p. II79. A. Hamilton, ed., The Chronicle of the English Augustinian Canonesses (Edinburgh and London, I904-6), I, p. 84. For the use of Ignatius and Xavier water in the Upper Palatinate, see Johnson, 'Blood, tears and Xavier-water'.

77 Foley, Records, VII, pt 2, pp. I097, IIO7, II42-3, respectively and see II, p. 6; vII, pt 2, pp. I099-IOO. István Tóth has discovered similar examples in mission records relating to Hungary: 'Books distributed, books destroyed: books in seventeenth-century Catholic missions in Hungary and Transylvania' (unpublished paper). $\quad{ }^{78}$ Scribner, 'Cosmic order and daily life', p. I2.

${ }^{79}$ Cf. Gentilcore, "Adapt yourselves to the people's capabilities",', pp. 293, 295.

80 Foley, Records, vII, pt 2, p. Iog8. $\quad{ }^{81}$ Ibid., vII, pt 2, p. II34. $\quad{ }_{82}$ Ibid., VII, pt 2, pp. II $3^{2-3}$. 
Elizabethan compilation, the heretical husband of a sick gentlewoman who recovered after receiving extreme unction turned to Rome after seeing 'the wonderful operation' of 'God's grace' in this sacrament. And a report from the Jesuits' Lincolnshire residence in the early i65os recorded the conversion of the Protestant sister of a noblewoman saved from death after one of the fathers recited the Litany of Our Lady of Loreto over her. ${ }^{83}$ In these ways the missionaries not only met the continuing need for ritual protection, but invested traditional practices with a distinctly Tridentine flavour.

\section{$\mathrm{V}$}

Nevertheless in a context in which the ratio of priests to people was low, it was extremely difficult to keep holy objects under close clerical control. The evergrowing arsenal of relics likewise defied attempts to maintain an ecclesiastical monopoly on the sources of supernatural power. These problems were partly a function of the fact that English Catholicism lacked fixed holy locations where the clergy could channel, manage, and restrain popular piety. The Reformation brought an end to the flow of pilgrims to Canterbury and Walsingham and the authorities briskly suppressed cults which sprang up at the sites of prodigies like the symbol of the Cross discovered in the trunk of an ash tree on the Glamorganshire estate of Sir Thomas Stradling in ${ }_{5} 56{ }^{84}{ }^{84}$

A notable exception to this general pattern was St Winifred's Well in North Wales, to which Catholic pilgrimages in search of thaumaturgic cures continued virtually uninterrupted. This should not be seen as a mere throwback to an earlier era, an example of Catholic survivalism untouched by the winds of the Tridentine revival. There are hints that the Jesuits actively tried to promote the cult of this seventh-century virgin as a focal point of devotion to the resurgent Church of Rome ${ }^{85}$ One manifestation of this enterprise was the circulation of miracles witnessed at Holywell in the post-Reformation period. More than a few concerned crippled Protestants who went there as a last resort and came away leaving both their crutches and the reformed faith behind them. In the i66os, for example, a poor man who travelled to the site from Worcestershire became a good Catholic after having been both a Quaker and an Anabaptist. ${ }^{86}$ Other springs were distinguished by wonders, including one which appeared suddenly in Oxford near the spot where one of the quarters of the martyred priest George Napper was hung in I6II, until it was stopped up by order of John King, vice-chancellor and dean of Christ Church. ${ }^{87}$

${ }^{83}$ Morris, Troubles, III, p. 54; Foley, Records, II, p. 647.

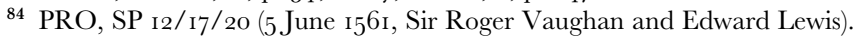

${ }^{85}$ See my 'Holywell: contesting sacred space in post-Reformation Wales', in Will Coster and Andrew Spicer, eds., Sacred space: the redefinition of sanctity in post-Reformation Europe (Cambridge, forthcoming).

${ }^{86}$ Foley, Records, IV, pp. $5^{18}$ and ${ }^{28} 8-37$. For many other miracles associated with Holywell, see Annalecta Bollandiana, 6 (1887), pp. 305-52.

${ }^{87}$ Questier, ed., Neresletters, p. 99. 
However, in a Protestant state there was little scope for transforming such sites into elaborate baroque shrines like those on the Continent which benefited from the patronage of the papacy or powerful rulers like the Wittelsbachs and Hapsburgs, notably Loreto in Ancona, Altötting in Bavaria, and Halle and Mont-aigu in the Spanish Netherlands. ${ }^{88}$ Nor, in the absence of a hierarchy of bishops and a network of parish priests, was there much room for channelling the enthusiasm of pilgrims in a theologically acceptable direction and eliminating any disturbing pagan overtones. ${ }^{89}$ Instead, their transient appearance may be attributed to the resilience of what William Christian has called 'local religion' ${ }^{\text {90 }}$ The zealous laity did not wait for official sanction; they spontaneously created new outlets for the ancient practice of pilgrimage in a manner which implicitly challenged the normal order of relations between people and priests. Margaret Clitherow and other pious York women, for instance, made secret nocturnal journeys barefoot to Knavesmire, half a mile outside the city, to pray beneath the gallows on which several clergy were executed in ${ }^{5} 522^{91}$ Others domesticated these devotional impulses, redirecting them into private spaces: Richard Sheldon poked fun at papists who set up in their gardens and orchards little carved images made from the wood of the oak tree associated with the wonder-working Marian icon at Sichem and made solemn daily visitations to them. ${ }^{92}$ Where the Church of Rome was dominant it left an indelible mark on the landscape; in England, it was obliged to depend for the most part on sources of supernatural power which could be carried in a missionary's pack and swiftly conveyed out of sight.

\section{I}

One type of 'ecclesiastical magic' which did lend itself well to an itinerant priesthood was ritual expulsion of demons. The most celebrated example of this form of thaumaturgy was the series of exorcisms conducted by a team of twelve seminary priests headed by the Jesuit William Weston in ${ }^{5} 5^{8} 5^{-6}$, when several servants and adolescents were dispossessed at the houses of Sir George Peckham at Denham in Buckinghamshire and of Lord Vaux at Hackney. ${ }^{93}$ But many other priests were acclaimed for their skill in casting out devils, including

88 On Loreto, see Bireley, Refashioning of Catholicism, pp. I Io-I I. On Altötting, see Soergel, Wondrous in his saints, esp. ch. 6. For Mont-aigu and Halle, see n. $3^{2}$ above and Pieter Geyl, The Netherlands in the seventeenth century, I609-I648 (London, I96I), p. 29. See also Hsia, Social discipline, pp. I54-7.

${ }^{89}$ See Craig Harline's illuminating article 'Miracles and this world: the battle for Jesus Oak', Archiv für Reformationsgeschichte, 93 (2002), pp. 217-38. $\quad{ }^{90}$ Christian, Local religion.

91 John Mush, 'A true report of the life and death of Mrs Margaret Clitherow', in Morris, ed., Troubles of our Catholic forefathers, III, pp. 395-7.

92 Sheldon, Survey, p. 7o. See also Lisa McClain, 'Without church, cathedral or shrine: the search for religious space among Catholics in England, I559-I625', Sixteenth Century fournal, 33 (2002), pp. 38I-99. Ronald Hutton identifies a similar process of domestication in relation to other proscribed Catholic rites: 'The English Reformation and the evidence of folklore', Past and Present, I48 (I995), pp. 89-I I6.

${ }_{93}$ Modern historians owe their detailed knowledge of this notorious episode to Harsnet's Declaration of egregious popish impostures. The text is edited and contextualized by F. W. Brownlow in Shakespeare, 
John Cornelius, whose very approach was supposed to put them to flight. In Jacobean Lancashire Edmund Arrowsmith freed many from their troublesome guests with the help of his brethren. The Benedictine Edward Barlow, executed in $\mathrm{I} 64 \mathrm{I}$, also had a talent for dealing with these unwelcome visitors and in I708 it was said that the Dominican Robert Armstrong had made war against diabolical fiends at Hexham in Northumberland in the I66os 'so signally that his fame and sanctity are spoken of even to this day'. ${ }^{\mathbf{9 4}}$ Demand for this rite grew against the backdrop of the Anglican campaign against John Darrell and other puritan exorcists and particularly after the canons of I604 made it effectively illegal within the framework of the Church of England ${ }^{95}$ Indeed, the numerous cases of successful exorcism recorded in the Annual Letters place much emphasis on the inability and unwillingness of the Protestant ministry to help people molested by unclean spirits. In I6I4 it was said that the heretics 'spare no pains to keep possessed persons [,] whom they assert to be mere lunatics [,] from intercourse with our fathers'. ${ }^{96}$ The ambivalence of English Protestantism on this topic played directly into the hands of its Roman Catholic adversaries.

Far from a hangover from the medieval past, this branch of miraculous healing must be seen as a crucial arm of the Tridentine missionary campaign to reconcile schismatics and evangelize Protestants. ${ }^{97}$ Elsewhere in Europe, exorcism was a major engine of the Counter Reformation. In Augsburg, where the Jesuit Peter Canisius dramatically expelled demons from several members of the wealthy Fugger household, it was a centrepiece of the struggle to reclaim the city from Lutheranism. In France, a succession of well-publicized possession cases were likewise transformed into 'baroque spectacles', powerful vehicles for vindicating the Real Presence and vociferously denouncing the Huguenots. ${ }^{\mathbf{9 8}}$ In England too

Harsnett and the devils of Denham (London and Toronto, I993). See also Weston, Autobiography, ed. Caraman, pp. 24-7.

${ }^{94}$ For Cornelius, see Challoner, Memoirs, p. I98, and Foley, Records, III, p. 446. For Arrowsmith and Barlow, see Challoner, Memoirs, pp. 364, 395. For Armstrong, R. Bracey, ed., 'English Dominican papers', in Dominicana, Catholic Record Society 25 (London, I925), pp. Io9, I26.

95 See Thomas Freeman, 'Demons, deviance and defiance: John Darrell and the politics of exorcism in late Elizabethan England', in Peter Lake and Michael Questier, eds., Conformity and orthodoxy in the English Church, c. 156o-c. I66o (Woodbridge, 200o), pp. 34-63; Michael MacDonald, ed., Witchcraft and hysteria in Elizabethan London: Edward Forden and the Mary Glover case (London, I99I), pp. xix-xxvi. For the canon of I604, see Gerald Bray, ed., The Anglican canons, 1529-1947, Church of England Record Society 6 (Woodbridge, I998), pp. $3^{6} 3^{-5}$.

${ }^{96}$ Foley, Records, viI, pt 2, p. IO7I.

97 Cf. Bossy, English Catholic community, pp. 266-7, who emphasizes that it 'lies not on the periphery, but somewhere near the centre of ... the role of the Catholic priest in England' until the mid-seventeenth century, yet sees it not as 'a novel departure' but as a persistence of a medieval tradition of clerical healing.

98 Lyndal Roper, 'Exorcism and the theology of the body', in her Oedipus and the devil: witchcraft, sexuality and religion in early modern Europe (London, I994), pp. I72-7; D. P. Walker, Unclean spirits: possession and exorcism in France and England in the late sixteenth and early seventeenth centuries (London, I98I), ch. 2 and pp. 75-7; Henri Weber, 'L'exorcisme à la fin du XVIe siècle, instrument de la contre réforme et spectacle baroque', Nouvelle revue du seizième siècle, I (I983), pp. 79-Ior ; Irene Backus, Le miracle de Laon (Paris, I994). See also István György Tóth, 'The missionary and the devil: ways of conversion in 
the clergy seem to have systematically exploited exorcism as a potent metaphor of and a practical mechanism for the expulsion of heresy. Sometimes the performance of this highly theatrical rite took on the appearance of a revivalist meeting: the demoniacs were placed in a chair where their strange contortions and writhings and the needles, pins, and other foreign objects expelled from their bodies could clearly be seen by an assembled crowd of spectators.

According to Protestant polemicists like Samuel Harsnet and Richard Sheldon, the aim of all these 'lewd practices' was 'the gaining of soules for his Holines, and for Hell'. The exorcists ingeniously orchestrated the proceedings with the intention that the bystanders might 'be persuaded of some point of poperie, or of the Priests power over the devills'. ${ }^{99}$ While we should be wary of accepting these claims about cynical clerical manipulation of these situations too literally, it is certainly true that they provided an excellent forum for illustrating the immense power of sacred words, symbols, relics, sacramentals, and the Catholic ministry itself. An element of conscious or subconscious collusion between exorcists and demoniacs cannot be entirely dismissed. At Denham and Hackney, Campion's girdle caused the possessing devils excruciating pain and they were no less allergic to a bone of his fellow martyr Alexander Briant. Clerical amices, stoles, gloves, and stockings all played a key role in routing the demons and in one of his trances Richard Mainy discerned 'a glistering light' emerging from the anointed thumbs and forefingers with which the missionaries handled the body of Christ in the mass. $^{100}$

Sectarian conflict was often at the heart of such episodes. In many, the devil negatively demonstrated the veracity of the Catholic religion by aligning himself firmly with the falsehood of Protestantism. The possessed were used like ventriloquists' puppets to reveal their approval of Queen Elizabeth and her ministers and to declare that the heretics were their friends and confederates. In I620, the 'Boy of Bilson' in Staffordshire violently tore and bit his clothes to delineate the hideous torments now endured by Luther, Calvin, and Foxe. ${ }^{101}$ In the course of their blasphemous ravings and during those lucid moments when the Father of Lies was compelled to tell the truth, the demoniacs also confirmed contested dogmas like transubstantiation, purgatory, and the Immaculate Conception. In the midst of receiving the sacrament, Sarah Williams saw the Infant Jesus in the chalice and she later wept for her father and mother because they were not recusants, insisting that the souls of those who attended Protestant churches were damned. ${ }^{\mathbf{1 0 2}}$

\footnotetext{
Catholic missions in Hungary', in Eszter Andor and István György Tóth, eds., Frontiers offaith: religious exchange and the constitution of religious identities, I4OO-I750 (Budapest, 200I), pp. 79-87.

99 Harsnet, Declaration, p. I50; Sheldon, Survey, p. 24. See also Gee, Foot out of the snare, ch. 6.

100 Harsnet, Declaration, pp. 55, 83-4, I63, I86, 249 (relics), pp. 64, 75, 8I-2, 89 (priest's garments), p. 272 (anointed thumb and finger).

101 Ibid., pp. I50-I; Richard Baddeley, The boy of Bilson (London, I622), p. 27.

102 Harsnet, Declaration, pp. I57-8 (transubstantiation and purgatory), I62 (Immaculate Conception), I99 (Infant Jesus in chalice); I56 (attendance at Protestant churches).
} 
In all these instances, Satan was prevailed upon to act as a catechist. The antiCatholic pamphleteer Richard Baddeley sought to turn this curious paradox to polemical advantage when he remarked: 'If the devils be made ... Messengers of divine truths, by the power of your Exorcismes, why doe you indeavour to expell them? ${ }^{103}$

Exorcism was a compelling demonstration of Catholicism's ability to triumph over the forces of evil, and it is not surprising that it made many converts. One witness thought that no fewer than 500 persons had been reconciled to the Roman Church as a consequence of the dramatic events at Denham; others estimated 3,000 or 4,000. ${ }^{104}$ In 1598 , priests in Lancashire exorcized several women in front of a large crowd drawn to this exercise by 'the novelty thereof', by which device, it was said, 'they win daily many unto them' ${ }^{105}$ A significant number of the ${ }^{1} 17$ conversions listed in the reports of the Jesuit residence in Durham for the years I638-9 appear to have been the consequence of miraculous ejections and their success in this area seems to have inspired the Fathers to extend their mission into the mountains of Westmorland. ${ }^{106}$ The Jesuit Christopher Southworth supervised another wave of dispossessions in the county in 1612 and some sixty persons were apparently delivered from thraldom by Satan in the same region in I626. ${ }^{107}$

By circulating news of these prodigious feats of dispossession in handwritten tracts and 'books of miracles', the Jesuits and their seminary colleagues sought to extend the impact of these dramatic episodes to a wider audience. ${ }^{108}$ In the process of preserving these tales of deliverance from the Archfiend, the clergy once again deftly refashioned them as lessons in the hazards of outward conformity and the joys of release from the prison of Calvinism. Thus exorcism had no effect on a lady who vacillated until she acted according to her conscience in I639; when she lapsed once again, her affliction returned. The same thing happened to a distressed student at Oxford who yielded to the temptation to attend a Protestant service not long after his formal reconciliation to Rome. In another example reported in the annual letter for $\mathrm{i} 655$, a girl was so eager to be received into the Church that she prayed to God that she might be possessed because this would force her hostile Protestant father to bring in a priest. ${ }^{109}$ As with other cures, the missionaries stressed that permanent liberation from possession by demons was dependent upon a steadfast commitment to the Roman Catholic religion.

\footnotetext{
103 Baddeley, Boy of Bilson, p. 46.

104 Harsnet, Declaration, p. 248.

105 Historical Manuscripts Commission, Salisbury, viII, pp. 2I3-I4, 293.

106 Foley, Records, III, pp. 122-3.

107 Southworth's exploits are discussed in Thomas Potts, The wonderfull discoverie of witches in the countie of Lancaster (London, I6I3); Foley, Records, vII, pt 2, p. II22.

108 Weston's 'book of miracles' circulated in recusant households: Harsnet, Declaration, p. I. Baddeley's tract on the Boy of Bilson incorporated a manuscript tract prepared by 'J. W.', possibly the priest 'Mr Wheeler': Boy of Bilson, p. 54 .

109 Foley, Records, viI, pt 2, p. II43; Challoner, Memoirs, pp. II8-I9; Foley, Records, II, pp. 2 I-2.
} 
Nevertheless, exorcism was not a risk-free strategy. Possession cases were unstable and unpredictable, and the antics of adolescent demoniacs had a disturbing tendency to invert and overturn the established age, gender, and social hierarchy. In particular, such incidents held the dangerous potential to invest the victims of diabolical assault with a mystique and esteem which could rival and even eclipse the aura which accumulated around the clerical exorcists who treated them. They had the capacity temporarily to empower the laity. ${ }^{110}$ Ostentatious publicity about such thaumaturgic triumphs also had its drawbacks. Above all it might expose the Catholic faith to damaging allegations of sorcery and deceitful fabrication. This is probably why English casuistry manuals recommended circumspection and secrecy when performing the rite and it may also account for the clergy's preference for disseminating accounts of these sensational events in the more select and less promiscuous medium of manuscript. ${ }^{111}$

These anxieties gave rise to some significant frictions and divisions within clerical ranks. 'Divers auncient priests' were greatly perturbed by the proceedings of the group led by Weston in $15^{8} 5^{-6}$ and 'did shake their heads' at the introduction into England of such foreign 'devises'. The 'graver sort' imprisoned in Wisbech said that 'howsoever for a time wee might be admired, yet in the end wee would thereby marre all, and utterly discredit both ourselves and our calling'. ${ }^{112}$ Their fear that this theatrical rite might prove a double-edged sword was undoubtedly compounded by the confessions to fraud which Richard Bancroft extracted from the Denham demoniacs, the damaging revelations of the apostate Anthony Tyrrell (one of the officiating priests), and the scandal caused by their publication by Samuel Harsnet in I603 ${ }^{113}$ The case of William Perry, the 'Boy of Bilson', whose pretence was revealed by Thomas Morton, bishop of Coventry and Lichfield, in I620 must also have increased a sense of vulnerability to the age-old charge of miracle-mongering. ${ }^{114}$ For others, though, the potential advantages of these 'baroque spectacles' far outweighed their possible perils. In the midst of the Denham affair, William Thompson declared that 'godlie credulitie doth much good ... for the defacing our common enemies' and Thomas Stamp averred that 'they were things of such importance, as would further the Catholique cause, more then all the bookes that had been written of late yeeres, about the controversies in Religion with the Protestants'. ${ }^{115}$ Exorcism, therefore, exposed a delicate faultline between missionaries who preferred to err on the

110 See J. A. Sharpe, 'Disruption in the well-ordered household: age, authority and possessed young people', in Paul Griffiths, Adam Fox, and Steven Hindle, eds., The experience of authority in early modern England (Basingstoke, I996), pp. I87-212.

111 P. J. Holmes, ed., Elizabethan casuistry, Catholic Record Society 67 (London, I981), pp. I6, 89-90.

112 Harsnet, Declaration, p. 254.

113 The examinations of Sara and Friswood Williams, Anne Smith, Richard Mainy and Anthony Tyrrell are printed at the end of Harsnet's Declaration.

114 Baddeley, Boy of Bilson, pp. 6I-75.

115 Harsnet, Declaration, p. 251. 
side of humanist caution and those who were willing to take the risks linked with evangelical enthusiasm.

\section{I I}

These themes reappear when we turn to the subject of prophecies and visions. They too could be a useful instrument for proving that the Church of Rome was the institutional embodiment of Christian truth. We have already seen that it was often difficult to decide whether demoniacs were mouthpieces of the devil or envoys from heaven. Sometimes their utterances sounded very much like the doctrinal pronouncements of a preacher or the inspired speeches of a prophet or seer, and like the latter quite a few possessed adolescents experienced pentecostal raptures in which they saw sights which transcended the natural. ${ }^{116}$ Two Catholic maids exorcized by Edward Hands at the Gatehouse at Westminster around I6I6, for instance, were said to have been corporeally possessed by the spirits of the Virgin Mary, John the Baptist, the Archangel Michael, and two Tyburn martyrs. These strange symptoms were apparently infectious: shortly afterwards Hands himself was 'cast into a deepe admirable ecstasie' and found himself a vessel for the Blessed Trinity. While in his trances, his soul saw 'very supernaturall and admirable joyes' and he spoke in the name of the Father, Son, and Holy Ghost. Thirty years earlier, Richard Mainy had been vouchsafed an apparition of Our Lady accompanied by angels, together with a premonition of his own imminent translation to Paradise. William Weston was so impressed that he fell prostrate in Mainy's presence, though he later became more ambivalent about the origin of the young gentleman's pronouncements. ${ }^{117}$ Like inquisitors on the Continent, the missionary leaders were instinctively suspicious about the motives of ordinary men and women who experienced mystical visions. ${ }^{118}$ However, the English clergy were not always so equivocal. Claims by the laity to have been privileged with divine revelations could represent a challenge to priestly authority, but they could also be very useful auxiliaries to an organization denied access to the pulpit and the public press.

In February I58I, for instance, a young Welsh girl called Elizabeth Orton fell into a series of ecstasies during which she saw visions of the fire of purgatory and a celebration of the Eucharist by John the Baptist, attended by Christ, the

\footnotetext{
116 On the confusion between prophecy and possession, see H. C. Erik Midelfort, 'The devil and the German people: reflections on the popularity of demon possession in sixteenth century Germany', in Stephen Ozment, ed., Religion and culture in the Renaissance and Reformation, Sixteenth Century Essays and Studies II (Kirksville, I989), esp. pp. II2-I8; Walsham, Providence, pp. 203-I8.

117 Gee, Foot out of the snare, ed. Harmsen, pp. I3 ${ }^{-2}$; Harsnet, Declaration, pp. $273^{-6 .}$

118 See Mary Elizabeth Perry, 'Beatas and the Inquisition in early modern Seville', in Stephen Haliczer, ed., Inquisition and society in early modern Europe (London, I987), pp. I47-68; eadem, Gender and disorder in early modern Seville (Princeton, I990), ch. 5; Anne Jacobsen Schutte, Aspiring saints: pretense of holiness, inquisition, and gender in the Republic of Venice, ${ }_{6} 6{ }_{1} 8-1750$ (Baltimore and London, 200I); Stephen Haliczer, Between exaltation and infamy: female mystics in Golden Age Spain (New York, 2002).
} 
Virgin Mary, and the eleven apostles. These were described in detail to the inquisitive crowd which collected at her house and circulated scribally in a pamphlet probably written by a former schoolmaster of the town by the name of 'Sir Hughes', a 'vile runnagate papist' whom she later accused of seducing her to participate in this extraordinary stratagem. Copies of this 'true report' were apparently sent to France, Rome, and Ireland and its author was almost certainly a priest trained at Douai who had recently returned to his native county to pursue his vocation. In the course of her reveries, Elizabeth Orton exclaimed against the Protestant religion and vowed never to attend their 'accursed Service again'. When examined afterwards about the mass she had seen in her miraculous vision, she agreed that it was in all points identical to 'the Romaine use restored by the Counsaile of Trent, and preached by the Seminarie [s] in England'. ${ }^{119}$ The whole incident was thus finely tuned to reinforce both the doctrine of recusancy and the Tridentine liturgy. Protestant commentators drew predictable parallels between the teenager and the ill-fated 'Holy Maid of Kent', whose contrived prophecies against the Henrician Reformation led to her exposure as a fraud and her execution for treason in $1534 .{ }^{120}$ The notorious nun had several other Elizabethan imitators. In I588, one Marie Taylor made revelations in support of the mass. Five years later a maid was imprisoned in Winchester after awaking from a fifteen-day coma, predicting that Elizabeth I would die before Michaelmas, and telling how she had seen Mary Tudor and Mary Queen of Scots in heaven and Henry VIII and the earl of Leicester in hell. ${ }^{121}$

Once again it is probably best to sidestep the issue of how far these occasions were stage-managed by priests working with impressionable lay people. What should rather be emphasized is the frequency with which visions served to incite Protestants to convert, confirm Catholics wavering in their faith, or convince young women to enter a convent in the Low Countries. Many apparitions of Christ in the mass were mentioned in Jesuit memoranda and as early as I574 Richard Bristow recounted how a recusant tempted to attend church by the threatenings of the churchwardens had seen 'a foule blacke dogge' at the moment the 'naughty minister' administered 'to the wretched people that devilish communion'. ${ }^{122}$ According to the Society's annual reports, a profligate soldier became a Roman Catholic in 1647 following a dream in which the Virgin Mary saved him from falling over a precipice and a heretical woman was received

\footnotetext{
119 Rich, True report, quotations at sigs. Dir, D4r. For Hughes, see Godfrey Anstruther, The seminary

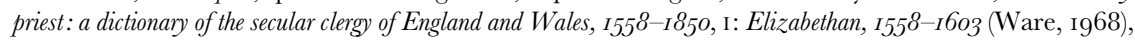
p. 178 .

120 See Alan Neame, The Holy Maid of Kent: the life of Elizabeth Barton, I506-I534 (London, I97I). The accounts of Catholic prophets like Elizabeth Barton and Elizabeth Orton operate within the conventions of a much older hagiographical tradition: see Ethan H. Shagan, 'Print, orality and communications in the Maid of Kent affair', Journal of Ecclesiastical History, 52 (200I), pp. 2I-33.

121 Thomas, Religion and the decline of magic, p. I54; Anthony G. Petti, ed., The Letters and despatches of Richard Verstegan (c. I550-c. I640), Catholic Record Society 52 (London, 1959), pp. 177, I80.

${ }^{122}$ Foley, Records, II, pp. 645-7, vII, pt 2, p. II78; Weston, Autobiography, ed. Caraman, p. 36. Bristow, Motives, fo. 39a.
} 
into the Church in 1635 after seeing the Madonna and Child during a dangerous illness. ${ }^{123}$ John Gee devoted much of his New Shreds of the Old Snare (I624) to exposing how the popish priesthood used 'the engine of personated Apparitions' to ensnare unwary Protestant girls into overseas nunneries and persuade rich young heiresses to part with their fortunes. Mary Wiltshire, for instance, became a Poor Clare after the Virgin or an angel appeared to her in a dream; the ghost of Mary Boucher's godmother returned to instruct her in the doctrine of transubstantiation and advise that heretics had no hope of entering heaven; and St Lucy manifested herself to Frances Peard, promising that if she adopted a religious life in Brussels she would be spared the searing pains of purgatory after her death. Gee's scurrilous claims that these illusions were produced by 'paper lanthornes', 'transparent glasses', or priests in white sheets are perhaps best treated as a colourful variation on the familiar theme of popish duplicity. However, buried beneath the polemical commonplaces around which his pamphlet was constructed lies yet more evidence of the success with which the missionary clergy cultivated the supernatural as an evangelical tool. After Francis Peard's vision, two priests came to her saying: 'You may see what it is to be a Catholicke and to be of our Church. Thus doth God worke his Miracles amongst us daily, and by such visions ... commonly reveale himselfe unto us. ${ }^{124}$

The recurrent attempts by the ecclesiastical and civic authorities to unmask the recipients of visions as charlatans, witches or crazed fanatics may attest indirectly to the credit they won among the common people. The case of Edward Hands, for instance, was taken so seriously that he was examined by a panel of five bishops, the dean of Westminster, and a doctor of laws. ${ }^{125}$ Even so, such episodes always held the potential to engender fresh charges of Machiavellian deception. For these and other reasons prophecies were a source of embarrassment to some sections of the Counter Reformation ministry. This is particularly apparent in the case of Thomas Newton, a Lincolnshire gentleman who claimed in I6I2 that the Virgin Mary had visited him in his cell in Stamford gaol and warned him against swearing the Oath of Allegiance. Dressed in a shining white robe, bearing a crown on her head, and surrounded by resplendent light, the apparition also affirmed the validity of invoking the saints and the Bodily Assumption of the Mother of Christ. Newton's heavenly revelation led to the conversion of his Protestant companion and bedfellow Edward Sutton and brought about a change of heart in a high-born lady who was so eager to embrace the Catholic faith that she undertook a long journey on foot to be reconciled by a priest. $^{126}$

123 Foley, Records, vII, pt 2, p. I200, II, p. 400.

124 John Gee, New shreds of the old snare (London, I624), quotation at pp. I, I7, I3. Gee, Foot out of the snare, ed. Harmsen, p. I56. Gee's allegations were part of a well-established Protestant tradition: see, for instance, the broadsheet concerning a Jesuit who dressed as a devil in ${ }_{5} 69 \mathrm{~g}$ in an effort to frighten an Augsburg maiden into abandoning her faith: Walter L. Strauss, The German single-leaf woodcut, I550-I60o, III (New York, I975), p. I335. $\quad{ }^{125}$ Gee, Foot out of the snare, ed. Harmsen, p. I8I.

126 Foley, Records, VII, pt 2, I056. A manuscript account of the vision is printed in Roger Widdrington [Thomas Preston], A theologicall disputation concerning the Oath of Allegiance, dedicated to the most 
Protestant polemicists were quick to alight upon it as another blatant popish imposture: Richard Sheldon wrote an entire treatise against this Marian phantom, though it remained unpublished because the government considered Newton 'fitter for Bedlam'. ${ }^{127}$ He languished in prison for the rest of the decade and was still being censored by the High Commission in January I62I for feigning the vision. ${ }^{128}$ These claims were echoed by the Benedictine monk Roger Widdrington in a tract championing the oath, the publication of which was almost certainly sponsored by the Jacobean government. In it he went to great lengths to demonstrate that the apparition was either 'the vehement imagination of a troubled braine' or 'a meere illusion of Satan'. ${ }^{129}$ Miracles had once more become a focus for the fractious internal politics of the post-Reformation English Catholic priesthood.

\section{I I I}

Finally, we must consider the ways in which the English Counter Reformation was accompanied by the emergence, or rather re-emergence, of a cult of living saints. Medieval Christianity had always found space for holy persons bearing Weberian charisma, individuals whose intense devotion, extreme asceticism, and skill in miraculous healing made them objects of veneration by their neighbours and peers. ${ }^{130}$ Emblematic of popular involvement in the making of the sacred, this pattern of piety was not extinguished by the onset of Protestantism. Sometimes the spotlight fell on prodigious children and adolescents. Towards the end of Elizabeth's reign, a young maid with 'a flaming or glittering apron' which gave off little flashes of lightning was apparently 'adored' in the city of London; after her removal to a convent abroad, many continued to repair to her for benediction. ${ }^{131} \mathrm{~A}$ few years later, the young seventh son of a committed Catholic couple became famous for curing the deaf, blind, and lame by placing his hands upon them and saying a prayer. ${ }^{132}$ The pious Northumberland widow Mrs Dorothy Lawson was another lay person who came to be honoured by her contemporaries as a figure of unique virtue and grace. Her pious dedication to attending upon mothers in labour led many superstitiously to regard her presence as indispensable for a safe delivery. She was also said to have prophesied the rise of Armininianism and was once seen by her husband in two places at once. At her deathbed 'melodious musick' was heard and three years later her rosary

\footnotetext{
holy father Pope Paul the Fifth ([London], I6r3), pp. 257-81. See also Gee, Foot out of the snare, ed. Harmsen, p. 133 and see pp. $182-3$. ${ }^{127}$ Sheldon, Survey, p. 175 .

${ }_{128}$ See CSP Domestic, I6II-I6I8, p. II, and CSP Domestic, I6I9-I623, p. 229; Acts of the Privy Council, I6I3-I4, p. 388; Bodleian Library, Oxford, Tanner MS 290, fo. 49r.

${ }^{129}$ Widdrington, Theologicall disputation, p. 276.

130 See Aviad M. Kleinberg, Prophets in their own country: living saints and the making of sainthood in the later Middle Ages (Chicago, 1992).

${ }^{131}$ Baddeley, Boy of Bilson, p. 8; John Gee, Hold fast (London, I624), p. 44.

132 George Roberts, ed., The diary of Walter Yonge ... from I604 to I628, Camden Society, Ist ser., 4I (I848), p. I3; Pricket, Fesuits miracles, sig. B4v; Sheldon, Survey, p. I8I.
} 
allegedly cured a woman of a terrible fever. Refracted through the hagiographical life composed by her confessor, here is further evidence of the continuing vitality of regional devotions in a Counter Reformation world dominated by a drive towards universalization. Like many obscure Italian and Spanish beatas, Dorothy Lawson was never elevated to the ranks of the officially canonized. ${ }^{133}$

However, it was the clergy rather than laity who most frequently acquired an aura of saintliness. Brother Thomas Oglethorpe of Yorkshire died 'in the odour of sanctity' only sixteen months after being admitted a novice of the Society of Jesus in I6I6. In the course of his godly life many had allegedly obtained favours by his intercession and a few days before his death he had been 'rapt out of his senses' by an apparition of the Virgin Mary flanked by the figures of Francis Xavier and Ignatius Loyola. Grieving admirers fought over his beads, clothes, writings, and pens, believing that these items had absorbed some of his holiness. ${ }^{134}$ The Jesuit Stephen Rowsome enjoyed a reputation as a saint even before he received the crown of martyrdom in 1587 . He saw many heavenly sights during a lifetime of 'singular perfection' and was often visited in prison by God the Father, Christ, Mary, and the saints, who left behind them 'odiferous smells'. ${ }^{3}$ In John Cornelius, executed seven years later, humility, austerity, and charity were conjoined with a proclivity for visions and awesome powers as an exorcist. ${ }^{136}$ We may suspect that the memory of the old man who recalled how Robert Southwell's head and face were radiant with light when he preached was coloured by hindsight, ${ }^{137}$ but it is clear that many Jesuit missionaries were revered as sacred figures by the populace - much like their counterparts in the kingdom of Naples, where 'pious credulity' led people to crowd around them during disasters in the hope of protection and cut off pieces of their habits to preserve as de facto sacramentals. ${ }^{138}$ In a similar case recounted by Gee, a kinswoman of Richard Conway was freed from vexation by the devil by anointing herself with oil into which a priest who had prayed for her had mingled his tears. ${ }^{139}$ Such spontaneous cults tested the boundary between proper respect for the clergy as a sacred caste of intermediaries and a 'superstitious' veneration of them which made Roman Catholicism ripe for merciless Protestant mockery.

England had nothing to compete with the Ingolstadt visionary Jakob Rem, who levitated in front of an icon of Our Lady in I6o4 or the 'flying saint'

\footnotetext{
${ }^{133}$ William Palmes, The life of Mrs Dorothy Lawson, of St Anthony's, near Newcastle-upon-Tyne, ed. G. Bouchier Richardson (Newcastle-upon-Tyne, I853 edn), p. 40 ; (London, I855 edn), ch. 9. Curiously the first edition does not include several of these 'testimonies above ordinary of her sanctity'. For beatas, see Gentilcore, From bishop to witch, ch. 6; Schutte, Aspiring saints; Hsia, World of Catholic renewal, ch. 9; and Gabriella Zarri, 'Living saints: a typology of female sanctity in the early sixteenth century', in Daniel Bornstein and R. Rusconi, eds., Women and religious in medieval and Renaissance Italy (Chicago, I996), pp. 219-303. $\quad{ }^{134}$ Foley, Records, III, pp. I68-73, VI, pp. 265-6.

${ }^{135}$ Ibid., IV, p. 340; 'An ancient editor's notebook', in Morris, Troubles, III, pp. 41-2.

${ }^{136}$ Foley, Records, III, pp. 445-50. $\quad{ }^{137}$ Ibid., vII, pt 2, p. II 36

138 Gentilcore, "“Adapt yourselves to the people's capabilities", pp. 288-9. For similar examples from other contexts, see Chatellier, Religion of the poor, pp. I02-3, Io6-7.

${ }^{139}$ Gee, Foot out of the snare, ed. Harmsen, p. I27.
} 
Giuseppe da Copertino, who lived a life of severe mortification and experienced multiple ecstasies. ${ }^{140}$ But it did have its fair share of thaumaturgic healers in the mould of the Italian Capuchin Marco d'Aviano, whose missionary tours of southern Germany in I680 were marked by many dramatic medical miracles. ${ }^{141}$ In the $\mathrm{I} 620 \mathrm{~s}$ one Jesuit father was said to be dispensing blessings and curing diseases in the place of his namesake, St Lawrence, after being transported in his sleep to a monastery in Spain. ${ }^{142}$ During the Interregnum an Irish priest called James Fienachty or Finnerty practised dispossession in the English capital by 'stroaking' and in the years preceding the appearance of the celebrated Protestant thaumaturge Valentine Greatrakes several members of the Society of Jesus seem to have been engaged in magical healing, including a certain Father James who was commonly renowned as 'a good man and a worker of wonders'. ${ }^{143} \mathrm{In}$ the summer of 1663 , another Irish clergyman called Blake wrought miraculous cures in London and Westminster for the space of five weeks, expelling evil spirits and restoring the sick and physically handicapped by laying his hands upon their heads, making the sign of the cross, and reciting some sentences in Latin. Many of these cures were effected at public ceremonies at the Queen's Chapel at St James, to which patients appear to have been admitted by ticket. Once again the clergy sought to exploit these occasions to make fresh converts to the faith, widely publicizing cases like the blind Protestant woman who regained her sight and found that her spiritual eyes had opened at the same time. After the sufferings of James Barrow from Southwark were eased with the aid of holy water, candles, and a ribbon tied around his neck, friars flocked around his Protestant father and 'bade me make the Boy a Catholick'. Banished from the city, Blake moved on to the Mitre Inn in Oxford and from thence to Chester, where thousands came to see him eject the devil from a female demoniac accompanied by a flash of fire and a strong smell of brimstone. ${ }^{144}$ But it was not always easy for the Jesuits and their secular colleagues to contain the fervour and emotion unleashed by such spectacles within the parameters of Catholic orthodoxy, or to counteract the

${ }^{140}$ On Rem, see Johnson, 'Blood, tears and Xavier-water', p. 200; on Guiseppe da Copertino, Gentilcore, From bishop to witch, pp. 165-8, I76.

${ }^{141}$ See Johnson, 'Recatholicisation', pp. 267-84, and the broadsheet picture Vera effigies A. R. P. Marci de Aviano (1680) [British Library classmark I750, c.2]. The Spanish Jesuit Miguel de Ochoa was reputed to have similar gifts. See John W. O'Malley, The first fesuits (Cambridge, MA, I993), p. 268.

${ }^{142}$ Gee, Hold fast, pp. $4^{2-3}$.

${ }^{143}$ Richard Hunter and Ida Macalpine, eds., Three hundred years of psychiatry, I535-I86o (London, I963), p. I5I; Anslem Faulkner, 'Father O'Finaghty's miracles', Irish Ecclesiastical Record, 5th ser., I04 (1965), pp. 349-62; John Heydon, Theomagia, or the Temple of Wisdome (London, I664), p. 224. See also British Library, Sloane MS I926, fo. $4 \mathrm{r}$ (a tract against Valentine Greatrakes), for a reference to a 'Master Summer'. On Greatrakes, see Eamon Duffy, 'Valentine Greatrakes, the Irish stroker: miracle, science and orthodoxy in Restoration England', in Keith Robbins, ed., Religion and humanism, Studies in Church History I7 (Oxford, I98I), pp. 25I-73.

144 A. S., Miracles not ceas'd (London, I663), citation at p. 22; John Barrow, The Lord's arm stretched out in an answer of prayer (London, I664), p. Io; Andrew Clark, ed., The life and times of Anthony Wood, antiquary of Oxford, I632-1695, I: $163_{32-1663}$, Oxford Historical Society I9 (I89I), p. 486; CSP Domestic, I663-1664, p. 243 . 
impulse of the populace to idolize such figures as magicians and shamans. Some such healers overstepped the line with regard to the thaumaturgic techniques they employed and there was a dangerous tendency for the laity to assume that their powers were somehow transferable. In the I66os, for instance, John Digby, son of the Catholic royalist Sir Kenelm, fell under the spell of Father Finnerty before travelling to France to work miracles on his own behalf 'by virtue of some sanctity' he had derived from the priest. When his skills went into decline, he set out for Ireland 'to fetch a new stock of the gift'. ${ }^{145}$

Nevertheless, all these examples attest eloquently to a developing cult of the priest as a conduit and funnel of sacramental grace. The relative scarcity of the Catholic clergy surely enhanced their charisma, even at the same time as it encouraged the laity to break the clerical monopoly on the use of blessed objects and employ them in a quasi-sacerdotal fashion. The missionary condition of the Church of Rome in England was not conducive to the assertion of priestly control over the sacred envisaged by the delegates at the Council of Trent. Persecution fostered a strong sense of popular Catholic identity centred on the martyrs and their miracles and relics but it also facilitated the development of devotion in directions which the Counter Reformation leaders must have regretted and lamented. It created conditions in which the tension between ecclesiastical direction and lay independence was unusually acute. As we have seen, it also helped to catalyse intra-clerical quarrels, to sow the seeds of conflict between those who shied away from sensational supernaturalism for fear of scandal and those who believed that in the battle to reverse the Reformation in England the clergy could not afford to neglect anything which testified to the ongoing ability of the Catholic Church to work astonishing wonders. The internal debate about the uses of miraculous power should not be mapped too neatly on to the factions that emerged in the years preceding the Archpriest controversy, but it may fruitfully be paralleled with the disputes which crystallized around the use of equivocation and mental reservation. ${ }^{\mathbf{1 4 6}}$ It too revolved around the problem of balancing prudence with proselytizing zeal and steering a course between high-risk strategies which might stain the integrity of the Catholic religion and a policy of guarded discretion which could doom it to slow and painful extinction.

\section{X}

The material discussed in this article emphasizes the importance of fully integrating post-Reformation English Catholic history into its wider international framework. Although they lacked the episcopal muscle and state support enjoyed by their European counterparts, the English seminary priests and especially the Jesuits creatively adapted and in some cases even anticipated the tactics that

${ }^{145}$ Gillespie, Devoted people, p. 68.

${ }^{146}$ See Johann P. Sommerville, "The "new art of lying": equivocation, mental reservation, and casuistry', in Edmund Leites, ed., Conscience and casuistry in early modern Europe (Cambridge and Paris, I988), pp. I59-84. 
would characterize the Catholic revival on the Continent in the seventeenth and eighteenth centuries, where itinerant rural missions conducted by the regular orders played a crucial part in the renewal of parochial life. They too found the supernatural an effective vehicle for confessional apologetic and used saints, relics, sacramentals, and exorcisms to rekindle enthusiasm for the renascent Church of Rome.

Arguably, the divine sanction provided by miracles was especially important to a religion which found itself on the defensive. Outlawed, persecuted, and struggling to avoid annihilation, English Catholicism had a particular need to prove its continuing immanence. In a context in which Protestantism had struck a sustained blow against traditional assumptions and practices, there was a strong incentive to re-emphasize the Church's power to work wonders through the agency of holy persons, sacred rituals, and consecrated objects. By extension, there is a distinct sense in which the English Catholic community was predisposed to see astonishing signs and wonders within its midst. With Bellarmine, the priesthood believed that miracles were an intrinsic feature of every 'extraordinary mission'. Comparing themselves with the earliest Christians, they expected God to demonstrate His support for their cause in the same way that He had convinced the sceptical Gentiles and Jews and succoured the faith of the oppressed apostolic congregations addressed in St Paul's epistles. Just as miracles had helped plant the primitive Church and underpinned Augustine's proselytizing initiatives in their own country, so too would they assist in the reclamation of England from heresy.

These insights have significant implications for our understanding of the nature and aims of the movement to train priests and send them back to work in a Protestant realm. They emphasize that those involved in this enterprise saw their task as one of 'conversion' rather than simply 'reconciliation'. To this extent, Christopher Haigh may be mistaken in arguing that the English Counter Reformation was 'less a spiritual crusade' than 'a series of adjustments' to the condition of proscription and that its personnel are better characterized as emissaries of a pastoral organization than of an evangelical operation. ${ }^{147}$ As we have seen, schismatics were not the sole focus of their efforts to graft meaning on to the miraculous: clerical attempts to utilize and publicize Rome's vast panoply of supernatural resources were directed as much at heretics as they were at church papists. In short, post-Reformation English Catholicism did regard itself as a missionary religion. William Allen intended the seminary priests to follow after the "example of the Apostles in their days' 148 and the English Jesuits

${ }^{147}$ Christopher Haigh, 'The continuity of Catholicism in the English Reformation', in idem, ed., The English Reformation revised (Cambridge, 1987), pp. 178, 194-5, 208. This view has been challenged by Michael Questier, Conversion, politics and religion in England, ${ }_{1580-1625}$ (Cambridge, 1996), ch. 7, esp. pp. I78-86. John O'Malley reminds us that they saw both conditions as springing from spiritual apathy and moral inertia: First Jesuits, p. 16.

${ }^{148}$ Robert Parsons, 'Of the life and martyrdom of Father Edmund Campion', Letters and Notices, $5^{8}$ (1877), pp. 219-42, 308-39, at p. 325 . 
modelled themselves on their intrepid colleagues in the Americas and Indies. Their dynamic, supple, and imaginative evangelism created as well as consolidated support for the Roman Catholic Church. It may be added that the fact of ecclesiastical disestablishment made the modus operandi of the Society of Jesus uniquely well suited to its endeavours in England.

In turn these observations suggest that the historical paradigm which pits continuity against conversion and survivalism against seminarism rather distorts our comprehension of the English situation. Although they occupy opposing positions in this now rather stagnant historiographical debate, for both John Bossy and Christopher Haigh the brand of Catholicism introduced by the seminary-trained missionaries into late sixteenth-century England embodied a profound break with the medieval past. Both imply that an immense gulf existed between the Catholicism of illiterate peasants and the Counter-Reformation spirituality priests brought with them from the Continent - between a faith rooted in rote-learned prayers, pilgrimages, relics, and sacramentals and an austere reformed piety which revolved around reading devotional texts, receiving the mass, and regular searching scrutiny of conscience. ${ }^{149}$ As I have argued here, however, the presumed polarity of pre- and post-Reformation Catholicism breaks down in the face of evidence that the Tridentine reformers endorsed and strengthened many characteristic traits of 'traditional religion' and readily harnessed preexisting elements of popular culture in the war against Protestantism. The religiosity of the recusant community which emerged in the late I570s may not have been as sharply distinct from the residual popery practised by many late Tudor Englishmen and women as we have been led to believe. Where the English mission succeeded in engendering a stalwart body of nonconformists, it perhaps did so not so much by cutting itself off from the familiar beliefs and observances of the 'Old Religion' as by embracing and building upon them. The challenges of working in an environment where Protestantism enjoyed institutional control may have stimulated clerical willingness to accommodate and reanimate older patterns of piety that were under attack.

Throughout the Elizabethan period, the clergy were dealing with a populace which had been baptized Catholics. They could capitalize on nostalgia for the ritual protection which had been supplied by the pre-Reformation Church and use survivalist feeling as a springboard in the quest to restore it to dominance. By the I62os, however, they were tackling a generation which had grown up as Protestants. Showing that the Lord continuously endorsed its doctrine by miracles and endowed its representatives with numinous power was crucial to proving that Catholicism was the single true religion. Startling signs and wonders must have added to the allure of a religion that already enjoyed the appeal of a forbidden fruit and an exotic foreign culture. And certainly miracles do seem to have played

149 Bossy, English Catholic community, p. 282; idem, 'The English Catholic community, I603-1625', in Alan G. R. Smith, ed., The Reign of James VI and I (Basingstoke, I973), p. Io4; Haigh, 'Continuity', esp. pp. 200, 207. 
a key role in the growth of recusancy in the early seventeenth century, particularly in London. In this regard, the vehemence of Protestant attacks on the Catholic culture of the supernatural cannot pass without notice. The very vigour and frequency with which reformed writers repeated the mantra that miracles had ceased embodies a candid admission that they faced an uphill struggle to combat these seductive 'new popish wonders'.

The evidence explored in this article may also raise questions about the extent to which the early Stuart priesthood as a whole had resigned itself to becoming a resident chaplaincy to the recusant nobility and gentry. The separation of the secular and Jesuit missions, which culminated in the appointment of the bishop of Chalcedon and the elevation of England into a full province of the Society of Jesus in I623, reflected a parting of ways between two different conceptions of the purpose and objectives of the enterprise launched half a century earlier. While the Appellants may have accepted Catholicism's status as a minority sect as a permanent state of affairs and sought to negotiate some form of toleration with the English government, there is reason to think that the Jesuits never completely relinquished their lingering hope that the country might once again return to obedience to Rome. After all, as events in the Upper Palatinate revealed, eighty years of Protestantism were no obstacle to the successful re-Catholicization of the region after i628. ${ }^{150}$ In the context of the Thirty Years War on the Continent, the possibility of military conquest and an aggressive state-led Counter Reformation could not be ruled out.

Ultimately, it remains difficult to plumb the depths of the piety to which the Catholic miracles we have examined gave rise - to assess how far respect for the Church of Rome's thaumaturgic capacities was matched by formal understanding of its doctrinal tenets, to decide whether the thirst for relics and sacramentals disguises a commitment which was only skin-deep, and to penetrate beneath the surface of the cults of holy personality surrounding martyrs and priests. ${ }^{151}$ What we can say with confidence is that they contributed significantly to the development of a Catholic confessional identity in post-Reformation England - even if this identity may have lacked the doctrinal knowledge and selfconsciousness which the clergy tried so hard to inculcate in the laity. The shortage of priests in this embattled community made the Counter Reformation effort to restrain superstition and profanity an even more formidable task than it was in other parts of Europe.

In these processes, the written and spoken word were critical. It was perhaps inevitable that most lay people would experience the wonders wrought on behalf of the Church of Rome vicariously, through the media of speech and of printed and manuscript tracts - and here I have proceeded from the assumption that miracles cannot be easily unravelled from the texts by which they were

150 Johnson, 'Recatholicisation'.

151 Cf. Gentilcore, "Adapt yourselves to the people's capabilities",, pp. 293-6; Gillespie, Devoted people, esp. conclusion. 
transmitted and in which they are now embedded. It was largely by this means that the clergy tailored miracle stories to coincide with Tridentine priorities and to deflect the taunts of their Protestant enemies. Filtered through the sieve of their missionary training, such narratives illuminate the manner in which they tried to teach their flocks correct conduct in the face of persecution and to instil in them an awareness of their theological differences with their heretical neighbours. In this respect at least they may indeed be labelled 'Ignatian fables'. But, as we have seen, tales of the martyrs and of cures worked by sacred objects also bear subtle traces of shaping by the laity. They reveal interesting wrinkles on the surface of the orthodox piety which the priests sought to project through saints' lives and moral exempla. They may be seen as both a symptom and a cause of the tensions and intersections between centre and periphery, clergy and laity, popular and elite, which lay at the core of post-Reformation English Catholicism and of the Counter Reformation as a whole. Scribally copied and verbally rehearsed by zealous lay people, such accounts defiantly eluded clerical attempts to dictate their interpretation and meaning. Like relics and sacramentals, they too sometimes became conduits and touchstones of the holy. Preserved as monuments of the martyrs and precious remnants of an heroic age of persecution, as time passed there was a tendency to regard them as miraculous themselves. 